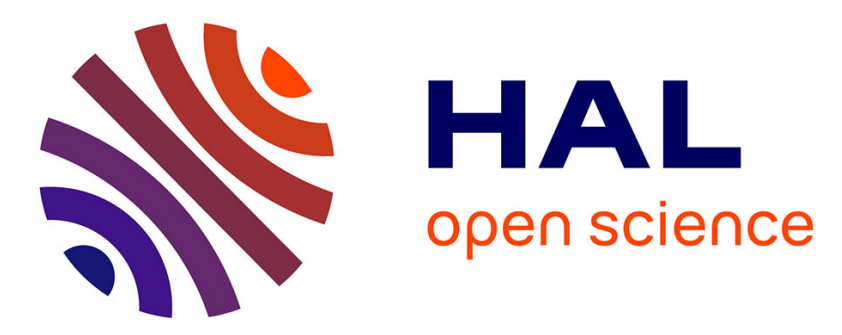

\title{
Biological Applications of Hydrophilic C60 Derivatives (hC60s) - a structural perspective
}

Xiaolei Zhu, Matthieu Sollogoub, Yongmin Zhang

\section{To cite this version:}

Xiaolei Zhu, Matthieu Sollogoub, Yongmin Zhang. Biological Applications of Hydrophilic C60 Derivatives (hC60s) - a structural perspective. European Journal of Medicinal Chemistry, 2016, 115, pp.438452. 10.1016/j.ejmech.2016.03.024 . hal-01288178

\section{HAL Id: hal-01288178 https://hal.sorbonne-universite.fr/hal-01288178}

Submitted on 14 Mar 2016

HAL is a multi-disciplinary open access archive for the deposit and dissemination of scientific research documents, whether they are published or not. The documents may come from teaching and research institutions in France or abroad, or from public or private research centers.
L'archive ouverte pluridisciplinaire HAL, est destinée au dépôt et à la diffusion de documents scientifiques de niveau recherche, publiés ou non, émanant des établissements d'enseignement et de recherche français ou étrangers, des laboratoires publics ou privés. 


\title{
Biological Applications of Hydrophilic $\mathrm{C}_{60}$ Derivatives $\left(\mathrm{hC}_{60} \mathrm{~S}\right)$ - a structural perspective
}

\author{
Xiaolei Zhu ${ }^{\text {a }}$, Matthieu Sollogoub ${ }^{\mathrm{a}}$, Yongmin Zhang ${ }^{\mathrm{a}, \mathrm{b}, *}$ \\ a Sorbonne Universités, UPMC Univ Paris 06, Insititut Parisien de Chimie Moléculaire, CNRS UMR 8232, 4 Place Jussieu, 75005 Paris, France \\ ${ }^{\mathrm{b}}$ Institute for Interdisciplinary Research, Jianghan University, Wuhan Economic and Technological Development Zone, Wuhan 430056, China
}

* Corresponding author.

E-mail address: yongmin.zhang@upmc.fr (Y. Zhang). Phone: +33.144276153

Abstract:

Reactive oxygen species (ROS) generation and radical scavenging are dual properties of hydrophilic $\mathrm{C}_{60}$ derivatives $\left(\mathrm{hC}_{60} \mathrm{~s}\right)$. $\mathrm{hC}_{60} \mathrm{~s}$ eliminate radicals in dark, while they produce reactive oxygen species (ROS) in the presence of irradiation and oxygen. Compared to the pristine $\mathrm{C}_{60}$ suspension, the aqueous solution of hC ${ }_{60} \mathrm{~s}$ is easier to handle in vivo. $\mathrm{hC}_{60}$ s are diverse and could be placed into two general categories: covalently modified $\mathrm{C}_{60}$ derivatives and pristine $\mathrm{C}_{60}$ solubilized non-covalently by macromolecules. In order to present in detail, the above categories are broken down into 8 parts: $\mathrm{C}_{60}(\mathrm{OH})_{\mathrm{n}}, \mathrm{C}_{60}$ with carboxylic acid, $\mathrm{C}_{60}$ with quaternary ammonium salts, $\mathrm{C}_{60}$ with peptide, $\mathrm{C}_{60}$ containing sugar, $\mathrm{C}_{60}$ modified covalently or non-covalently solubilized by cyclodextrins $(\mathrm{CDs})$, pristine $\mathrm{C}_{60}$ delivered by liposomes, functionalized $\mathrm{C}_{60}$-polymer and pristine $\mathrm{C}_{60}$ solubilized by polymer. Each $\mathrm{hC}_{60}$ shows the propensity to be ROS producer or radical scavenger. This preference is dependent on $\mathrm{hC}_{60} \mathrm{~s}$ structures. For example, major application of $\mathrm{C}_{60}(\mathrm{OH})_{\mathrm{n}}$ is radical scavenger, while pristine $\mathrm{C}_{60} / \gamma$-CD complex usually serves as ROS producer. In addition, the electron acceptability and innate hydrophobic surface confer $\mathrm{hC}_{60} \mathrm{~s}$ with $\mathrm{O}_{2}$ uptake inhibition, $\mathrm{HIV}$ inhibition and membrane permeability. In this review, we summarize the preparation methods and biological applications of $\mathrm{hC}_{60} \mathrm{~s}$ according to the structures.

Keywords: Hydrophilic $\mathrm{C}_{60}$ derivatives; ROS generation; Radical scavenger; Biological applications

\section{Introduction}

Hydrophilic $\mathrm{C}_{60}$ derivatives $\left(\mathrm{hC}_{60} \mathrm{~s}\right)$ serve as either photosensitizer or radical scavenger. The intriguing co-existence of two opposite capacities leads to in-depth study of $\mathrm{hC}_{60}$. The photodynamic ability has applications on DNA cleavage, antitumor, antibacterial activities etc., while the ability of absorbing radical causes hC ${ }_{60} \mathrm{~s}$ to be antioxidant agents. In most of state-of-the-art research, the native $\mathrm{C}_{60}$ is produced by two most common ways, Krätschmer-Huffman method and combustion of laminar flames of benzene and oxygen [1-3]. Both of the two methods generate $\mathrm{C}_{70}$ by-product, which is removed through chromatography [4]. The pristine $\mathrm{C}_{60}$ with poor hydrophilicity limits its further development. Three strategies are adopted to get biocompatible $\mathrm{hC}_{60} \mathrm{~s}$ : (1) the introduction of head-top groups on $\mathrm{C}_{60}$ cage, such as hydroxyl, carboxyl, quaternary ammonium salts, (2) the conjugation of small hydrophilic molecules (saccharides, peptides) via different linkers, (3) the encapsulation of macromolecules (CDs, liposomes and polymers). In this review, we present $\mathrm{hC}_{60} \mathrm{~s}$, their biological applications and try to explain them based on structures.

\subsection{Physicochemical property of $\mathrm{C}_{60}$}

Fullerene $\left(C_{n}, n\right.$ is an even number) is a spheroid made of at least 20 carbon atoms. The formation of the peculiar spheroid structure has been explained by a 'shrinkwrapping' mechanism [5]. Multiwall nanotubes wrap into the giant fullerenes, which will sublime several $\mathrm{C}_{2}$ and twine further to form the more stable $\mathrm{C}_{70}$ and $\mathrm{C}_{60}$. If the reaction continues, the carbon atoms are removed to form the smaller fullerenes (like $\mathrm{C}_{20}$ ), which are instable and prone to open and disappear irreversibly [6]. All of the fullerene members contain different number of hexagons and 12 pentagons which are essential to constitute the spheroid. Small fullerenes $\left(\mathrm{C}_{20} \leq \mathrm{C}_{n} \leq \mathrm{C}_{58}\right)$ have been predicted to possess narrow HOMO-LUMO gaps and high reactivity owing to the adjacent pentagons, which violate isolated pentagon rule (IPR) [7]. $\mathrm{C}_{60}$ is the first fullerene to conform to IPR and without any other IPR isomers, so is the second abundant fullerene $\mathrm{C}_{70}$. Larger fullerenes $\left(\mathrm{C}_{n} \geq 76\right)$ have at least 2 IPR isomers. The number of IPR isomers increases with the enlargement of the size of fullerene, except $\mathrm{C}_{84}$ (24 IPR isomers) and $\mathrm{C}_{86}$ (19 IPR isomers) [8].

$\mathrm{C}_{60}$, constituted by $60 s p^{2.28}$-hybridized carbon atoms, is an icosahedron of 12 pentagons which are separated by 20 hexagons [9]. Each carbon atom connects with each other by three non-planar $\sigma$ bonds, which leads to the angle strain and a $p$ orbit forming a large $\pi$ electron cloud. The angle between the $\pi$ orbital and $\sigma$ bond is $11.6^{\circ}$, while the angels of normal alkene and alkyl are $0^{\circ}$ and $19.47^{\circ}$, respectively [10]. The way to alleviate the angle strain is that $s p^{2.28}$-hybrid transforms to $s p^{3}$ hybride. These carbon atoms compose [6,6] bond (located between two fused 6-membered rings) and [5,6] bond fused by 5-and 6-membered rings. The pristine $\mathrm{C}_{60}$ is prone to produce [6,6] cycloadduct on account of [6,6] bond much closer to olefinic bond than [5,6] bond [9]. Various $\mathrm{C}_{60}$ adducts can be obtained through Bingel reaction [12-14], Diel-Alder reaction [15], [3+2] cycloaddition reaction, [2+2] cycloaddition reaction [16], SET-promoted photoaddition reaction [17] and other different addition patterns [18-20]. 


\section{$1.2 \quad$ ROS producer and Radical scavenger}

$\mathrm{C}_{60}$ behaves like an electron-deficient olefin attributed to poor electron delocalization. It could accept at most 6 electrons, which has been confirmed by 6 measured potentials $[21,137]$. The high electron affinity endows $C_{60}$ with radical scavenging ability [138].

$\mathrm{C}_{60}$ generates ROS under UV irradiation, even under white light (Fig. 1). The dominant one is single oxygen $\left({ }^{1} \mathrm{O}_{2}\right)$, quantitatively produced by oxygen accepting energy from ${ }^{3} \mathrm{C}_{60}$ (Type II Energy Transfer). ${ }^{3} \mathrm{C}_{60}$ with lower energy $\left(37.5 \mathrm{kcal} / \mathrm{mol}\right.$ ) is obtained via intersystem crossing from ${ }^{1} \mathrm{C}_{60}$ with relatively high energy (46.1 $\mathrm{kcal} / \mathrm{mol}$ ) (Fig. 1) [22]. If there are electron donor (such as, triethylamine and $\mathrm{NADH}$ ) in the solution, ${ }^{3} \mathrm{C}_{60}$ accepts an electron to form $\mathrm{C}_{60}{ }^{-}$(Type I Electron Transfer). $\mathrm{O}_{2}$ obtains the electron from $\mathrm{C}_{60}{ }^{--}$to get $\mathrm{O}_{2}^{-{ }^{-}}$, which is followed by disproportionation catalyzed by superoxide dismutase (SOD) and Fenton reaction. $\bullet \mathrm{OH}^{-}$ generated [23-25]. ROS is applied for tumor inhibition, antibacterial, DNA cleavage, delay of arthritic progress, etc..

\subsection{Pristine $\mathrm{C}_{60}$ suspensions and $\mathrm{hC}_{60} \mathrm{~s}$ in water}

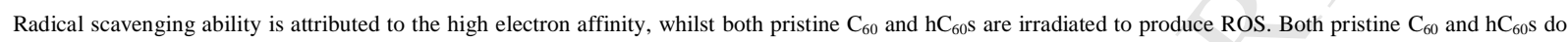
not have to affect the biological activities through the direct interaction with the target (protein, DNA, etc.) [139]. In fact, the inherent aggregation or cluster hinders pristine $\mathrm{C}_{60}$ from interacting with the target by a single $\mathrm{C}_{60}$ molecule. It is attributed to the poor solubility of pristine $\mathrm{C}_{60}$ in aqueous solution or polar solvents [140, 141]. $\mathrm{hC}_{60} \mathrm{~s}$ not only improve the water-solubility of pristine $\mathrm{C}_{60}$, but also decrease the $\mathrm{C}_{60}$ aggregation. Furthermore, the only exception is $\mathrm{C}_{60}$ derivatives as $\mathrm{HIV}$ inhibitors. The $\mathrm{C}_{60}$ cage binds directly to the big hydrophobic pocket of HIV aspartic enzyme. However, no paper has reported that pristine $\mathrm{C}_{60}$ shows $\mathrm{HIV}$ inhibition [81-84].

The pristine $\mathrm{C}_{60}$ suspensions can be obtained by simple solvent extraction, sonication or long-term stirring [142]. Although these preparation methods increase pristine $\mathrm{C}_{60}$ concentration in aqueous solution, large aggregates still exist. ROS producing ability will decrease with the growing aggregation. ${ }^{3} \mathrm{C}_{60}$, the indispensable intermediate to produce ROS, is sensitive to the outer environment. ${ }^{3} \mathrm{C}_{60}$ could be quenched by the surrounding $\mathrm{C}_{60}$ and another ${ }^{3} \mathrm{C}_{60}$ among $\mathrm{C}_{60}$ aggregates [26]. Besides, the aggregation reduces the diffusion rate of $\mathrm{O}_{2}$ [143]. The life time of ${ }^{3} \mathrm{C}_{60}$ is from tens to a hundred of microseconds in the solution of monomeric $\mathrm{C}_{60}$ analogues, while it lowers to less than $0.1 \mu \mathrm{s}$ in a $\mathrm{C}_{60}$ cluster [143]. In addition, the decreased area of the conjugated $\mathrm{C}_{60}$ reduces ${ }^{1} \mathrm{O}_{2}$ quantum yield [145]. Hence, ROS producing ability is dependent on low aggregation and relatively intact conjugated surface.

On the contrary, high degree of aggregation does not reduce the radical scavenging ability obviously. Fullerenol and $\mathrm{C}_{60}\left(\mathrm{C}(\mathrm{COOH})_{2}\right)_{3}$ with large aggregation erase radicals $[29-33,144]$. Their main ability is radical scavenging. Even if fullerenol is irradiated, its ROS producing ability is much weaker than that of $\mathrm{C}_{60} / \gamma$-CD complex [98]. Besides aggregation, the large amount of substitutions (such as, $-\mathrm{OH}$ ) on $\mathrm{C}_{60}$ cage disturb the conjugated system, causing weak ROS production [145].

The reminder of this review is organized as follows: Section 2 presents $\mathrm{C}_{60}(\mathrm{OH})_{\mathrm{n}}$, which are mainly as radical scavenger; Section 3 summarizes $\mathrm{C}_{60}$ with carboxylic acids, which are radical scavenger and weak ROS producer; Section 4 takes a look at $\mathrm{C}_{60}$ with quaternary ammonium salts, which are ROS producer, $\mathrm{O}_{2}$ uptake inhibitor, DNA or drug vector; in Section $\mathbf{5}$, we give a detailed study of $\mathrm{C}_{60}$ containing peptides, serving as radical scavenger, ROS producer, vector and HIV inhibitor; Section 6 is a brief introduction to $\mathrm{C}_{60}$ with sugar as radical scavenger, ROS producer and drug vector; Section 7 shows $\mathrm{CD}-\mathrm{C}_{60}$ conjugates and $\mathrm{CD} / \mathrm{C}_{60}$, which are ROS producer; Section 8 summarizes cationic liposome $/ \mathrm{C}_{60}$ as ROS producer and neutral liposome/ $\mathrm{C}_{60}$ as radical scavenger; Section 9 gives a deep analysis of $\mathrm{C}_{60}{ }^{-}$ polymer conjugates and $\mathrm{C}_{60}$ /polymer complex. In conclusion, we will review all the state-of-the-art of $\mathrm{hC}_{60} \mathrm{~s}$ on biology.

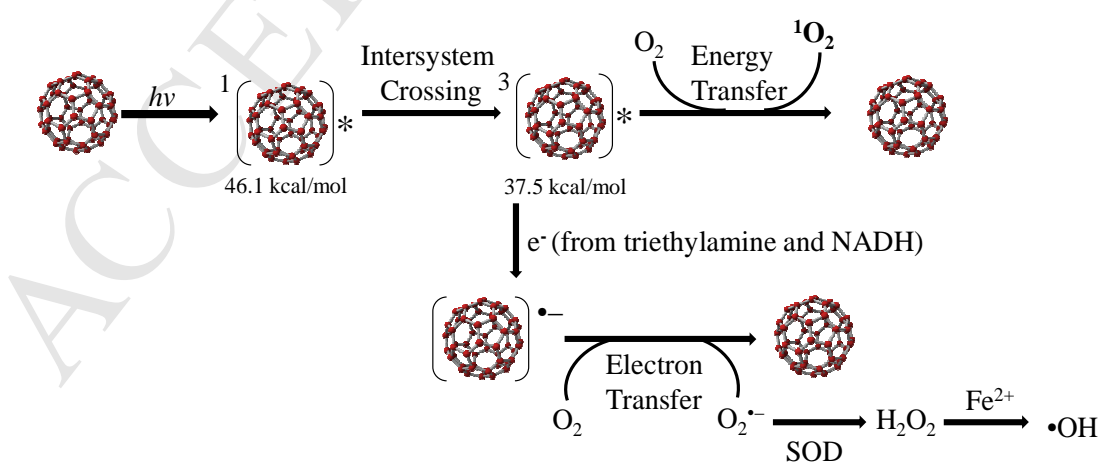

Fig. 1. ROS Generation

2. $\mathrm{C}_{60}(\mathrm{OH})_{\mathrm{n}}$ 
- $\mathrm{OHs}$ were introduced on $\mathrm{C}_{60}$ cage in order to improve the hydrophilicity of $\mathrm{C}_{60}$ by oxidative agents. The common agents were $\mathrm{H}_{2} \mathrm{SO}_{4} \cdot \mathrm{SO}_{3}, \mathrm{HNO}_{3}, \mathrm{O}_{2}$ and $\mathrm{H}_{2} \mathrm{O}_{2}$. The early work was that $\mathrm{C}_{60}(\mathrm{OH})_{18-20}$ expunge $\mathrm{O}_{2}{ }^{-}{ }^{-}$and was considered as radical scavenger [27, 28]. Other $\mathrm{C}_{60}(\mathrm{OH})_{\mathrm{n}}$ had the same effect to prevent the oxidative damages from DOX, X-ray, $\mathrm{H}_{2} \mathrm{O}_{2}$, lead and $\mathrm{CCl}_{4}$. The protective activity of $\mathrm{C}_{60}(\mathrm{OH})_{\mathrm{n}}$ was related to anti-aging, anti-inflammation and promoting bacterial growth [134-136].

\subsection{Radical scavenger: Prevent oxidative damage from DOX and $\mathrm{CCl}_{4}$}

$\mathrm{C}_{60}(\mathrm{OH})_{24}$ is taken as an antioxidant protector against the cardiotoxicity, pulmotoxicity, nephrotoxicity and hepatotoxicity induced by DOX [29-33]. $\mathrm{C}_{60}(\mathrm{OH})_{24}$ was obtained by the derivatization of $\mathrm{C}_{60} \mathrm{Br}_{24}$, which was afforded by $\mathrm{C}_{60}$ and bromide in the presence of catalytic amount of $\mathrm{FeBr}_{3}$ with the yield of 98\% [29, 34]. The above toxicities were attributed to free radicals generated by DOX in vivo. DOX was especially harmful to heart owing to the abundant mitochondria in cardiomyocytes. NADH dehydrogenase contained in the mitochondria reduced DOX to the semiquinone compound and the latter offered an electron to $\mathrm{O}_{2}$, inducing the production of $\mathrm{O}_{2}{ }^{--}$and $\mathrm{H}_{2} \mathrm{O}_{2}$ [35]. $\mathrm{C}_{60}(\mathrm{OH})_{24}$ was tested to the healthy rats with the co-treatment of DOX. The DOX alone group led to adrenalin-induced reflex bradycardia and vacuolization of cardiomyocites. The pre-treated $\mathrm{C}_{60}(\mathrm{OH})_{24}$ group delayed or even diminished these side effects [29]. In addition, 100 mg/kg $\mathrm{C}_{60}(\mathrm{OH})_{24}$ maintained the level of antioxidative enzymes superoxide in cardiomyocytes which would be enhanced by $8 \mathrm{mg} / \mathrm{kg}$ DOX. The enzymes contained SOD, catalase (CAT), glutathione peroxidase (GSH-Px) and glutathione reductase (GR) [35]. Lactate dehydrogenase (LDH) and $\alpha$-hydroxybutyrate dehydrogenase ( $\alpha$ $\mathrm{HBDH})$ in cardiomyocytes were marks to evaluate the tissue injuries. Both of them being elevated by DOX decreased by $\mathrm{C}_{60}(\mathrm{OH})_{24}[35]$. Except the cardioprotection, $\mathrm{C}_{60}(\mathrm{OH})_{24}$ prevented the oxidative injury from the lung and kidney as well. The rats received 1-methyl-1-nitrosourea (MNU, a carcinogen) were treated with $8 \mathrm{mg} / \mathrm{kg}$ DOX and $100 \mathrm{mg} / \mathrm{kg} \mathrm{C} 60(\mathrm{OH})_{24}$. Compared with the parameter of cardioprotection, GSH-Px activity in the lung and kidney was decreased by DOX and $\mathrm{C}_{60}(\mathrm{OH})_{24}$ maintained the level as the control [30,31]. The hepatoprotection of $\mathrm{C}_{60}(\mathrm{OH})_{24}$ showed that it downregulated the level of enhanced SOD, GSH-Px, GR, CAT and total antioxidant status (TAS). Nevertheless, MDA level of the group treated with $\mathrm{MNU} / \mathrm{C}_{60}(\mathrm{OH})_{24} / \mathrm{DOX}(8663 \mu \mathrm{g} / \mathrm{L})$ were much higher than the control $(970.7 \mu \mathrm{g} / \mathrm{L})$ and the MNU-DOX group $(5484 \mu \mathrm{g} / \mathrm{L})$. The plausible reason was the poor water-solubility of $\mathrm{C}_{60}(\mathrm{OH})_{24}$. About $20 \% \mathrm{C}_{60}(\mathrm{OH})_{24}$ remained on the ventral surface of the liver, pancreas and spleen of the rat after the intraperitoneal injection. It caused the increasing exudates in the abdomen and chest, leading to the significant change of alanine aminotransferase (ALT), aspartate aminotransferase (AST), and the ALT/AST ratio as well [32]. 20\% more DMSO in the physiological solution of $\mathrm{C}_{60}(\mathrm{OH})_{24}$ could maintain the level of MDA and these enzymes [33]. Besides, less amount of $\mathrm{C}_{60}(\mathrm{OH})_{\mathrm{n}}$ can avoid the side effect as well. $\mathrm{C}_{60}(\mathrm{OH})_{\mathrm{n}}(\mathrm{n}=22,24)$ at the dose of 5 $\mathrm{mg} / \mathrm{kg}$ decreased MDA, ALT and AST level. It showed hepatoprotection against $\mathrm{CCl}_{4}$-induced oxidative damage, which was coincident with pristine $\mathrm{C}_{60}$ suspension $[36,147]$. The further study showed that $\mathrm{C}_{60}(\mathrm{OH})_{24}$ had the cardioprotection and hepatoprotection on the chronic toxicity induced by DOX as well [33].

$\mathrm{C}_{60}(\mathrm{OH})_{16-24}$ not only lowered DOX toxicity towards heart, but also inhibited angiogenesis, which assisted DOX to inhibit tumor cells [37, 38]. PEG-C 60 (OH) ${ }_{16-24}-$ DOX inhibited the growth of mouse melanoma cell line B16-F10. Both of free DOX and PEG- $\mathrm{C}_{60}(\mathrm{OH})_{16-24}$-DOX decrease the tumor volume in the same level. Free

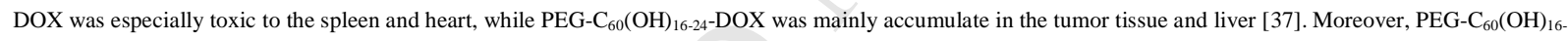
${ }_{24}$-DOX completely inhibited angiogenesis at the concentration of $100 \mu \mathrm{M}$ (calculated by DOX) and DOX alone did not show any inhibition. In other model to detect endothelial tubulogenesis, PEG- $\mathrm{C}_{60}(\mathrm{OH})_{16-24}$-DOX strengthened the tubulogenesis inhibition of either $\mathrm{C}_{60}(\mathrm{OH})_{16-24}$ or DOX at the concentration of $1 \mu \mathrm{M}$ and it did not bear the cytotoxicity [38].

\subsection{Radical scavenger: Protect cells from the radiation}

$\mathrm{C}_{60}(\mathrm{OH})_{24}$ improved the cell survival suffered from X-ray damage. X-ray of high dose (24 Gy) lowered the cell viability of human erythroleukemia K562 cells, $\mathrm{C}_{60}(\mathrm{OH})_{24}$ decreased the effect. Moreover, the cell survival of $\mathrm{C}_{60}(\mathrm{OH})_{24}$-incubated group without the irradiation was higher than that of control group [39]. With the irradiation of lower dose X-ray $(2 \mathrm{~Gy}), 10 \mu \mathrm{M} \mathrm{C}_{60}(\mathrm{OH})_{24}$ did not enhance obviously the cell survival. But the expression of anti-apoptotic and cytoprotective genes was modulated. Similarly, most of the cytoprotective genes were elevated with the pre-treated $\mathrm{C}_{60}(\mathrm{OH})_{24}$, such as CAT, Mn-SOD, nitric oxide synthase, glutathione Stransferase isoform GSTA4, glutathione peroxidase and gamma-glutamyltransferase [40].

\subsection{Other protection}

$\mathrm{C}_{60}(\mathrm{OH})_{\mathrm{n}}$ had other protective applications. $\mathrm{C}_{60}(\mathrm{OH})_{18-20}$ served as the antagonist of glutamate receptor to protect the nerve cells. It did not work with other receptors, such as $N$-methyl-D-aspartate (NMDA) and kainate receptor. $50 \mu \mathrm{M} \mathrm{C}_{60}(\mathrm{OH})_{18-20}$ inhibited $50 \%$ activity of glutamate $[41] . \mathrm{C}_{60}(\mathrm{OH})_{44} \cdot 8 \mathrm{H}_{2} \mathrm{O}$ prevented $\mathrm{UV}$-induced cell injuries to protect human keratinocytes [42]. The mixture $\mathrm{C}_{60} \mathrm{H}_{\mathrm{x}}(\mathrm{OH})_{\mathrm{y}}$ promoted the growth of Escherichia coli [43]. $\mathrm{C}_{60}(\mathrm{OH})_{34-36}$ inhibited the inflammation through reducing expression of interleukin- $1 \beta$ and toll-like receptor 4 [44]. $\mathrm{C}_{60}(\mathrm{OH})_{20}$ lowered the angiogenesis factors, leading the anti-tumor activity [45].

\subsection{Radical scavenger and ROS producer}

A recent study described that $\mathrm{C}_{60}(\mathrm{OH})_{\mathrm{n}}$ acted as both photosensitizer and antioxidative reagent [46]. Folic acid (FA) was introduced to target HeLa cells. DOXhydrazone- $\mathrm{C}_{60}(\mathrm{OH})_{21}$-FA was well dispersed in water and the aggregate was $135 \mathrm{~nm}$. $100 \mathrm{~nm}-200 \mathrm{~nm}$ was the best range of nanoparticles as drug attributed to the enhanced permeation and retention (EPR) effect [46, 119]. After the exposure of 460-485 nm light, hydrazone- $\mathrm{C}_{60}(\mathrm{OH})_{21}-\mathrm{FA}$ decreased the viability of $\mathrm{HeLa}$ cells from $100 \%$ to $60 \%$. ${ }^{1} \mathrm{O}_{2}$ quantum yield of hydrazone- $\mathrm{C}_{60}(\mathrm{OH})_{21}$-FA was 0.40 . Therefore, photodynamic activity strengthened the inhibition of DOX to HeLa cells. 
Furthermore, DOX-hydrazone- $\mathrm{C}_{60}(\mathrm{OH})_{21}$-FA was less toxic to HeLa cells than free DOX without the light irradiation. It was explained by the radical scavenging effect of $\mathrm{C}_{60}(\mathrm{OH})_{n}[46]$.

\section{3. $\mathrm{C}_{60}$ with carboxylic acid}

\subsection{Radical scavenger}

Malonic acid $\mathrm{C}_{60} \mathrm{~s}$, the mainly used carboxyfullerene $\left(\mathrm{C}_{60}\right)$, were synthesized through Bingel reaction and hydrolyzation (Fig. 2) [47].

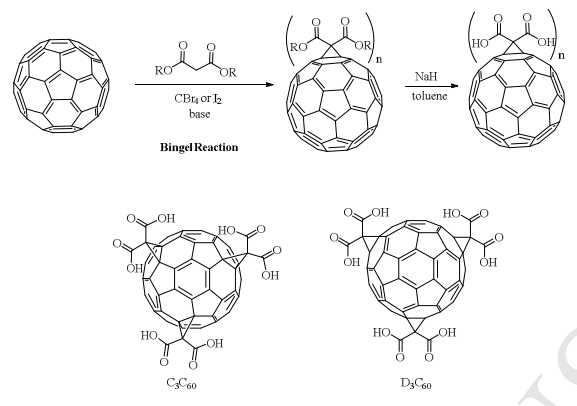

Fig. 2. Synthesis of Malonic Acid $C_{60}$ s and the structures of $C_{3} C_{60}$ and $D_{3} C_{60}$

$\mathrm{C}_{60}\left[\mathrm{C}(\mathrm{COOH})_{2}\right]_{3}$ had the innate radical scavenging ability, which was utilized to detect protease. Tri-malonic acid $\mathrm{C}_{60}\left[\mathrm{C}(\mathrm{COOH})_{2}\right]_{3}$ at the concentration higher than 5 $\mu \mathrm{M}$ quenched gradually the bioluminescence of the humanized Gaussia luciferase (hGluc). $\mathrm{C}_{60}\left[\mathrm{C}(\mathrm{COOH})_{2}\right]_{3}$ was linked with His-tagged hGlu through $\alpha$-thrombin cleavable sequence. If there was protease in the solution, $\alpha$-thrombin sequence was cleaved and the bioluminescence of hGlu was recovered [48].

Same as $\mathrm{C}_{60}(\mathrm{OH})_{n}, \mathrm{C}_{60}\left[\mathrm{C}(\mathrm{COOH})_{2}\right]_{3}$ prevented the oxidative damage. $\mathrm{C}_{3} \mathrm{C}_{60}$ and $\mathrm{D}_{3} \mathrm{C}_{60}$ were regioisomers of $\mathrm{C}_{60}\left[\mathrm{C}(\mathrm{COOH})_{2}\right]_{3}\left(\mathrm{Fig}\right.$. 2). $\mathrm{C}_{3} \mathrm{C}_{60}$ was more effective on antioxidative protection than $\mathrm{D}_{3} \mathrm{C}_{60}$. It was considered as two reasons: (1) $\mathrm{C}_{3} \mathrm{C}_{60}$ had the stronger interaction with the membrane [49, 50], (2) Because of the dipole structure, the $\mathrm{C}_{60}$ cage which was adjacent to the malonic acid group was electron-deficient. This area was potent to attract $\mathrm{O}_{2}{ }^{--}$. On the contrary, the electron density was even on the cage of $\mathrm{D}_{3} \mathrm{C}_{60}$ owing to the symmetrical distribution of malonic acid groups [51]. $\mathrm{C}_{3} \mathrm{C}_{60}$ reduced ROS and prevented the apoptosis caused by transforming growth factor- $\beta$ (TGF- $\beta$ ) and UVB. Both of TGF- $\beta$ and UVB enhanced ROS in human hepatoma Hep3B cells and keratinocytes, respectively. After the treatment with $\mathrm{C}_{3} \mathrm{C}_{60}$ at the concentration of $20 \mu \mathrm{M}$, more than $90 \%$ Hep3B cells were protected from apoptosis [50]. $25 \mu \mathrm{M}$ of $\mathrm{C}_{3} \mathrm{C}_{60}$ recovered the viability of keratinocytes after UVB irradiation. $\mathrm{C}_{3} \mathrm{C}_{60}$ reduced the activation of caspase-3, $-6,-8,-9$ and -10 , which caused by UVB-induced apoptosis. $\mathrm{C}_{3} \mathrm{C}_{60}$ regulated the molecular level of pro-apoptotic protein Bid, antiapoptotic protein Mcl-1 and Bad, while it did not work to bcl-1 [52]. Moreover, $\mathrm{C}_{3} \mathrm{C}_{60}$ prevented the neuronal apoptosis through decreasing $\mathrm{O}_{2}^{-{ }^{-}}$in the mitochondria. NMDA induced excitotoxicity was associated to $\mathrm{O}_{2}{ }^{-{ }^{-}}$production. $30 \mu \mathrm{M}$ of $\mathrm{C}_{3} \mathrm{C}_{60}$ kept the neuronal survival completely from NMDA. $\mathrm{C}_{3} \mathrm{C}_{60}$ had stronger effect than Vitamin $\mathrm{E}$ (less than $25 \%$ cell survival) [51]. The further study showed that the neuroprotection was beneficial for prolonging lifespan and ameliorating cognition of aged mouse [53]. Compared to the young mouse, $\mathrm{O}_{2}{ }^{-}$was elevated in the old mouse brain. $\mathrm{C}_{3} \mathrm{C}_{60}$ decreased the oxidative stress from $165 \%$ to $37 \%$ measured by the fluorescence of oxidative dihydroethidium. $\mathrm{C}_{3} \mathrm{C}_{60}$ enhanced $11 \%$ of the median lifespan. Besides, $\mathrm{C}_{3} \mathrm{C}_{60}$ elevated the spatial learning and memory performance of old mouse, which was comparative level as young mouse [53].

\subsection{ROS producer}

Malonic acid $\mathrm{C}_{60} \mathrm{~s}$ act as ROS producer when they were dispersed by human serum albumin (HSA) and PEG-modified poly(amidoamine) (PAMAM) dendrimer. Both of $\mathrm{C}_{3} \mathrm{C}_{60} / \mathrm{HSA}$ complex and malonic acid $\mathrm{C}_{60} \mathrm{~s} / \mathrm{PEG}-\mathrm{PAMAM}$ were non-toxic in dark. $\mathrm{C}_{3} \mathrm{C}_{60}$ was monomolecularly encapsulated by HSA. Because ${ }^{1} \mathrm{O}_{2}$ quantum yield of $\mathrm{C}_{3} \mathrm{C}_{60} / \mathrm{HSA}$ complex was 0.46 , same level as that of monomeric $\mathrm{C}_{3} \mathrm{C}_{60}(0.48)$. After the irradiation of 350-600 nm light, $\mathrm{C}_{3} \mathrm{C}_{60} / \mathrm{HSA}$ complex (20 $\left.\mu \mathrm{M}\right)$ induced $57 \%$ LY80 tumor cells death [54]. Mono-malonic acid $\mathrm{C}_{60}\left(\mathrm{MC}_{60}\right)$ and di-malonic acid $\left(\mathrm{DC}_{60}\right)$ were encased by PEG-PAMAM through hydrophobic interaction and electrostatic interaction (the tertiary amine of PAMAM and -COOH group of malonic acid $\mathrm{C}_{60} \mathrm{~s}$ ) [55]. MC 60 /PEG-PAMAM was more stable than DC 60 /PEG-PAMAM in physiological $\mathrm{pH} . \mathrm{MC}_{60}$ was released in the acidic environment. Because of EFR effect and the relatively acidic environment of tumor cells, PEG-PAMAM/MC 60 accumulated in the tumor cells and decreased the survival of HeLa cells from $80 \%$ to $30 \%$ under the laser irradiation [56].

\section{4. $\mathrm{C}_{60}$ with quaternary ammonium salts}

These cationic fullerenes were generated via methylation after 1,3-dipolar cycloaddition of $\mathrm{C}_{60}$ and azomethine ylides, synthesized by the amino acids and aldehydes, or aziridines (Fig. 3) [57]. Through Prato reaction, the different isomers were obtained and they showed the similar activity [58]. Therefore, the mixture of isomers was used to further biological applications. These cationic $\mathrm{hC}_{60}$ s were as $\mathrm{ROS}$ producer and DNA vector. 

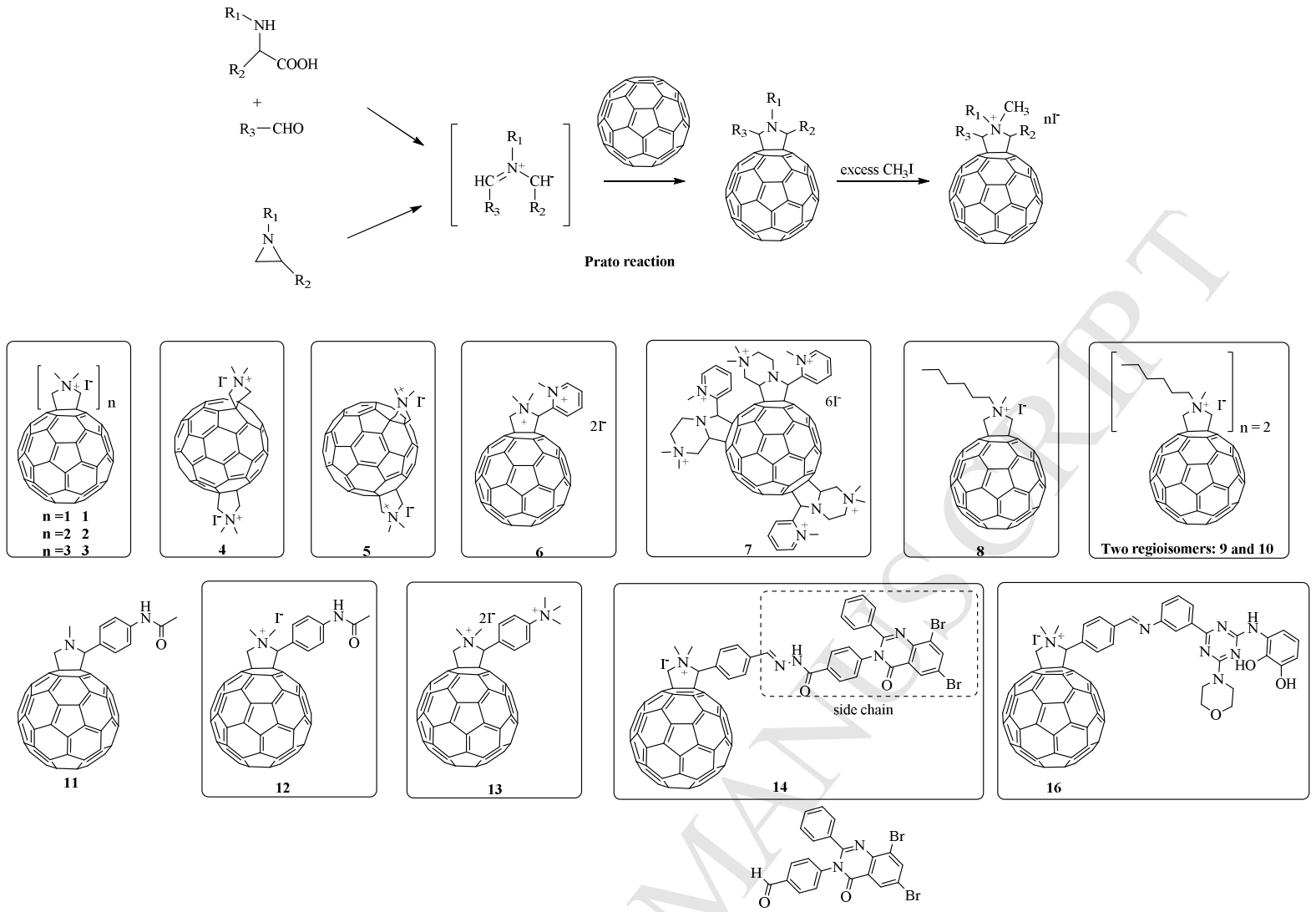

15

Fig. 3. Synthesis of $\mathrm{C}_{60}$ with Quaternary Ammonium Salts and Representatives

\section{1 $\mathrm{O}_{2}$ uptake inhibition}

The cationic $\mathrm{hC}_{60}$ s possessed inherently antibacterial activity owing to the acceptability of electrons. The inhibition of $\mathrm{O}_{2}$ uptake was on the inner-membrane [58-60]. This effect was more potent than that of di-malonic acid $\mathrm{C}_{60}$ [59]. Two processes were involved: cationic $\mathrm{hC}_{60} \mathrm{~s}$ at a low concentration consumed $\mathrm{NADH}$ which was indispensable for $\mathrm{O}_{2}$ uptake; cationic $\mathrm{hC}_{60} \mathrm{~s}$ at a high concentration were oxidized by $\mathrm{H}_{2} \mathrm{O}_{2}$ which was produced by $\mathrm{O}_{2}$. Both of the two processes restrained $\mathrm{O}_{2}$ absorption on the inner-membrane. Because of the different accumulation of $\mathrm{C}_{60}$ derivatives between the cell and inner-membrane, $\mathrm{C}_{60}$ derivatives inhibited bacterial growth more effectively than dioxygen uptake [58]. Cationic $\mathrm{C}_{60} 2$ (a mixture) showed a completely bacteriostatic effect on gram-negative bacterium $E$. coli at the concentration of $5 \mu \mathrm{M}$ and lowered saliently the dioxygen uptake at the concentration of $50 \mu \mathrm{M}$ [59]. The further study showed that compound 4 and $\mathbf{5}$, the regioisomers of cationic $\mathrm{C}_{60} \mathbf{2}$, had the similar bacteriostatic effect. $1 \mu \mathrm{M}$ of compound $\mathbf{5}$ completely inhibited $E$. coli, while the same effect needs $0.7 \mu \mathrm{M}$ of compound 4 [58].

\subsection{ROS producer}

$\operatorname{ROS}\left({ }^{1} \mathrm{O}_{2},{ }^{1} \mathrm{O}_{2}{ }^{--}\right.$and $\mathrm{OH} \bullet$ generation of cationic $\mathrm{hC}_{60}$ s led to bacterial inhibition as well. Both $\mathrm{NaN}_{3}\left({ }^{1} \mathrm{O}_{2}\right.$ quencher) and mannitol (the scavenger of ${ }^{1} \mathrm{O}_{2}{ }^{--}$and $\mathrm{OH} \bullet$ ) could prevent the inhibition [61]. Compared to mouse L929 fibroblasts, the inhibition was less than the microbes under the same incubation time [62]. Compound 2 at the concentration of $1 \mu \mathrm{M}$ killed 4-5 logs gram-positive bacteria $S$. aureus with $2 \mathrm{~J} / \mathrm{cm}^{2}$ of visible light (400-700 nm) [62]. 4 and 6 logs gram-negative bacteria E. coli with less easily permeable outer-membrane were dead after the treatment of compound $2(10 \mu \mathrm{M})$ under $2 \mathrm{~J} / \mathrm{cm}^{2}$ irradiation. With the irradiation of $16 \mathrm{~J} / \mathrm{cm}^{2}$, compound $\mathbf{2}$ engendered 3-5 logs bacterial death to gram-negative bacterium P. aeruginosa which was more resistant. Both compound $\mathbf{2}$ and $\mathbf{3}$ were more potent than compound 1 attributed to the cationic numbers. More cationic charges were beneficial for binding microbial membrane with negative charges [62]. The further study corroborated this result: compound $\mathbf{7}$ (with 6 cations) > compound $\mathbf{6}$ (with 2 cations), two regioisomers $\mathbf{9}$ and $\mathbf{1 0}$ (with 2 cations) > compound $\mathbf{8}$ (with 1 cation); compound $\mathbf{1 3}$ (with 2 cations) > compound $\mathbf{1 2}$ (with 1 cation) > compound $\mathbf{1 1}$ (without cation) [63, 64].

Although compound $\mathbf{3}$ with 3 cations had stronger inhibition against $S$. aureus than compound $\mathbf{2}$ with 2 cations, compound $\mathbf{2}$ and $\mathbf{3}$ showed the similar efficiency to $E$. coli and P. aeruginosa attributed to the relatively poor cellular uptake [62]. The gram-positive bacteria $S$. aureus absorbed compound $\mathbf{2}$ and $\mathbf{3}$ more easily than the 
gram-negative bacteria $E$. coli and P. aeruginosa. The gram-negative bacteria had the different constituents from gram-positive bacterium. The out layers of grampositive bacteria were consisted of peptidoglycan and lipoteichoic acid or $\beta$-glucan, cationic $\mathrm{hC}_{60}$ s penetrated easily into the bacterial cytoplasm. Nevertheless, gramnegative bacteria with the double membrane structure showed the diffuse barrier. The way to enter was "self-promoted uptake", that was, cationic $\mathrm{hC}_{60} \mathrm{~s}$ replaced with some necessary ions (such as $\mathrm{Mg}^{2+}, \mathrm{Ca}^{2+}$ ), attached lipopolysaccharide of the outer membrane and penetrated into the cells [65].

\subsection{Drug and DNA vectors}

Cationic $\mathrm{hC}_{60}$ s facilitated quinazolinone to approach and traverse the cell wall of mycobacteria so that they enhanced the efficiency of quinazolinone [66, 67]. Quinazolinone inhibited the indispensable enzymes for DNA replication. 12, with the minimum inhibitory concentration (MIC) $1.562 \mu \mathrm{g} / \mathrm{mL}$ against $\mathrm{Mycobacterium}$ tuberculosis, was much more potent to disturb the cell growth of mycobacteria than the contrast $\mathbf{1 5}$ with MIC of $200 \mu \mathrm{g} / \mathrm{mL}$. Because of the introduction of $\mathrm{C}_{60}, \mathbf{1 4}$ (MIC $=6.25 \mu \mathrm{g} / \mathrm{mL}$ ) can sneak into the cytoplasm and facilitate the quinazolinone to inhibit the enzymes. Additionally, the cations of $\mathbf{1 4}$ interacted with the carboxylic groups of mycolic acid in the cell envelope of mycobacterium cell wall [66]. From molecular docking, 14 was possible to inhibit hypoxanthine-guanine phosphoribosyltransferase. $\mathrm{C}_{60}$ part of $\mathbf{1 4}$ was in a pocket of charged amino acid, containing Lys66, Glu122, Leu123, Asp126, Lys154, Asp182 and Asp188 [68].

Cationic $\mathrm{hC}_{60} \mathrm{~s}$ delivered DNA through hydrophobic interaction and electrostatic attraction [69]. 16 bound to pBR322 DNA minor groove via hydrophobic interaction. Its $\mathrm{C}_{60}$ cage bound to guanosines, which were G81, G83 and G85 at the forward strand as well as G33 at the reverse strand. Furthermore, the side chain of $\mathbf{1 6}$ had the H-bond, $\pi-\pi$ stacking and electrostatic interaction with DNA as well [70].

\section{5. $\mathrm{C}_{60}$ with peptide}

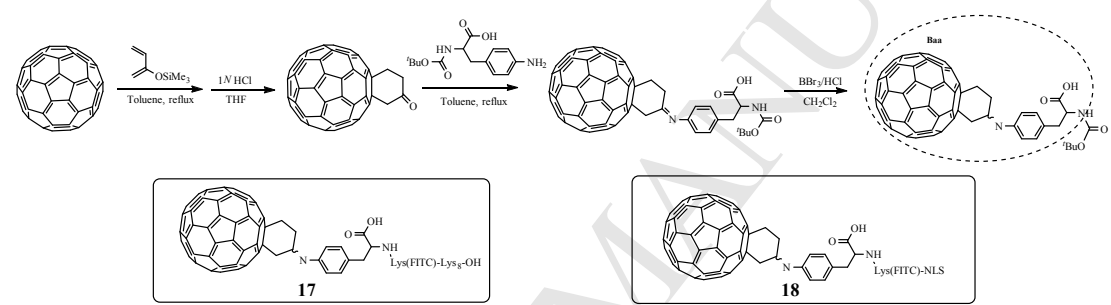

A: Synthesis of Baa and Representatives

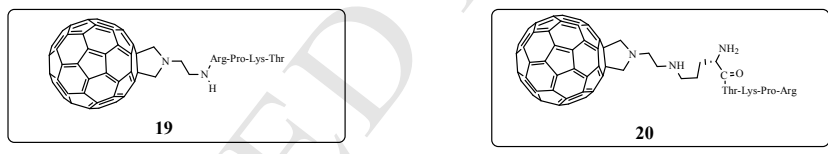

B: $\mathrm{NH}_{2}$-tuftsin- $\mathrm{C}_{60} 19$ and $\mathrm{C}_{60}$-tuftsin-COOH 20

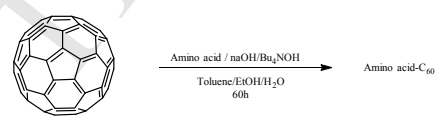

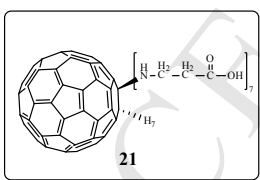

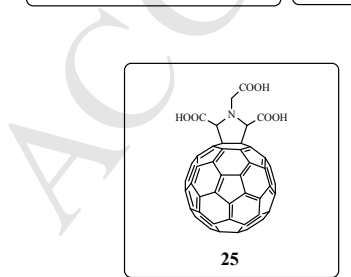

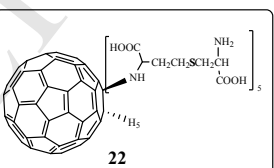

C: $\mathrm{C}_{60}$

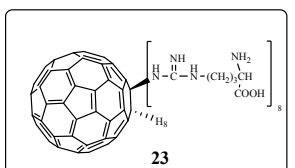

23
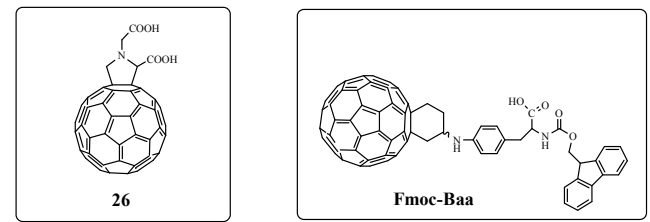

D: $\mathrm{C}_{60}$-amino acids derivatives 25, 26, Fmoc-Baa

Fig. 4. $\mathrm{C}_{60}$ with peptides

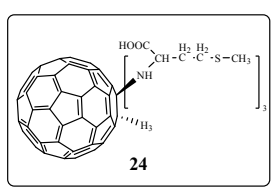

24 
The less substitution on $\mathrm{C}_{60}$ cage led to stronger antioxidant protection. $22(135.8 \mathrm{~nm})$ and $23(376.9 \mathrm{~nm})$ were much bigger than 21 (9.5 $\left.\mathrm{nm}\right)$ attributed to the selfassemble of $\mathbf{2 2}$ and $\mathbf{2 3}$ through bidentate hydrogen bonds (Fig. 4). $-\mathrm{COOH}$ interacted with $-\mathrm{NH}_{2}$ of another molecule and $-\mathrm{NH}_{2}$ bound to $-\mathrm{COOH}$ of another molecule. The cellular permeability was $\mathbf{2 1}>\mathbf{2 2}>\mathbf{2 3}$ owing to the easy penetration into cells with the small aggregate sizes. Although all of them showed the similar efficiency on scavenging $\bullet \mathrm{OH}, \mathrm{O}_{2}^{-}$scavenging efficiency was $\mathbf{2 2}>\mathbf{2 1}>\mathbf{2 3}$ attributed to the number of $\mathrm{C}=\mathrm{C}$. The most cell survival was shown by the protection of $\mathbf{2 2}$. 21 decreased the amount of apoptotic cells most efficiently from oxidative damage induced by $\mathrm{H}_{2} \mathrm{O}_{2}(800 \mu \mathrm{M})$ [71]. Other research indicated the cytoprotective effect of $\mathbf{2 4}$ (more than $100 \%$ of the cell viability) was slightly better than $\mathbf{2 1}$ (less than $90 \%$ ) and $\mathbf{2 2}$ (less than $100 \%$ ) at $50 \mu \mathrm{g} / \mathrm{mL} . \mathbf{2 4}$ at the same concentration reduced malondialdehyde amount (caused by lead-induced oxidative stress) from $0.50 \mathrm{nmol} \cdot \mathrm{mg}^{-1}$ to $0.21 \mathrm{nmol} \cdot \mathrm{mg}^{-1} \mathrm{protein}^{[72]}$.

\subsection{ROS producer}

$\mathrm{C}_{60}$-Phe and $\mathrm{C}_{60}$-Gly generated ROS. After the irradiation of a 25-W incandescent lamp for 30 min, $\mathrm{C}_{60}$-Phe led to $21.8 \%$ human breast cancer cell line MCF-7 apoptosis at the concentration of $320 \mu \mathrm{g} / \mathrm{mL}$, while $\mathrm{C}_{60}$-Gly $(300 \mu \mathrm{g} / \mathrm{mL})$ induced $41.25 \%$ cell apoptosis. The two $\mathrm{C}_{60}$-amino acids caused a significant decrease on cell amount in G2/M and S phase. The pre-incubation of NAC (a radical scavenger) attenuated the cell apoptosis to $9.47 \%$ and $8.79 \%$, respectively. Furthermore, NAC lowered the damaged DNA and p-p38 level caused by $\mathrm{C}_{60}$-Phe and $\mathrm{C}_{60}$-Gly [73].

\subsection{ROS producer and Radical scavenger}

HSA stabilized $\mathrm{C}_{60}$ in water. $\mathrm{C}_{60} / \mathrm{HSA}$ was obtained via the exchange reaction between $\mathrm{C}_{60} / \mathrm{CD}$ derivative and HSA. The stable $\mathrm{C}_{60} / \mathrm{HSA}$ aqueous solution maintained the size from $160 \mathrm{~nm}$ to $200 \mathrm{~nm}$ during 15 days. $\mathrm{C}_{60}$ changed the secondary structure of HSA, which was indicated by the decreased Trp214 fluorescence. Without light exposure, $\mathrm{C}_{60}$ strengthened the antioxidant ability of HSA. HSA had this protective effect because of cysteine residue. $50 \%$ scavenging activity required $16.5 \pm$ $2.81 \mu \mathrm{M} \mathrm{C}_{60} / \mathrm{HSA}$ and $22.3 \pm 2.25 \mu \mathrm{M}$ free HSA. Under the irradiation of visible light, $\mathrm{C}_{60} / \mathrm{HSA}$ produced the comparable amount of $\mathrm{O}_{2}^{-{ }^{-}}$with $\mathrm{C}_{60} / \mathrm{PNVP}^{-}$and large amount of ${ }^{1} \mathrm{O}_{2}[74,75]$.

\subsection{Delivery}

Highly hydrophobic $\mathrm{C}_{60}$ cage delivered peptides to the internal membranes. $\mathrm{C}_{60}$-alanine and $\mathrm{C}_{60}$-alanylalanine quenched the erythrosine triplet both outside and inside of artificial membranes. On the contrary, $\mathrm{Co}^{2+}$ erased the phosphorescence of erythrosine outside [76]. Baa was synthesized by $\mathrm{C}_{60}$ and an amino acid (Fig. 4) [77]. Baa-Lys(attached with fluorescein isothiocyanate (FITC))-Lys ${ }_{8}-\mathrm{OH} 17$ and Baa-Lys(FITC)-nuclear localization sequence (NLS) 18 passed through the cells membranes (human embryonic kidney epithelial cell line, HEK-293), while Lys(FITC)-Lys 9 and Lys(FITC)-NLS cannot [78]. Except the hydrophobic effect of C 60 , Lys was beneficial to delivery as well. When parts of Lys were replaced with negatively charged Glu, Baa-Lys-(FITC)-Glu 4 -Gly $-\mathrm{Ser}_{3}-\mathrm{OH}$ showed relatively weak cellular uptake. It was attributed to the electrostatic interaction of positive charge of Lys with the negatively charged phospholipid membrane [78]. The further study was explored. 18 (20 $\mu \mathrm{M}$ in 1\% PBS) penetrated epidermis and localized within the intercellular spaces of the stratum granulosum after flexing the skin for 90 min. The permeable ability made $\mathrm{C}_{60}$ with peptide as a potential drug delivery [79].

The steric hindrance of $\mathrm{C}_{60}$ prevented tuftsin (Thr-Lys-Pro-Arg) to decompose by leucine aminopeptidase. Tuftsin is an immunostimulating agent. Compared to tuftsin, $\mathrm{C}_{60}$ enhanced the stimulation of phagocytosis and chemoattractant effect. $\mathrm{C}_{60}$-tuftsin- $\mathrm{COOH} 20$ at the concentration of $20 \mu \mathrm{mol} / \mathrm{L}$ led to the highest phagocytosis and $\mathrm{NH}_{2}$-tuftsin- $\mathrm{C}_{60}$ at the same concentration reached the best chemotaxis. Both $\mathrm{NH}_{2}$-tuftsin- $\mathrm{C}_{60} \mathbf{1 9}$ and $\mathbf{2 0}$ stimulated the expression of major histocompatibility complex class II (MHC II), which was expressed against antigens. Tuftsin was not able to affect MHC II expression. In addition, 20 and 19 improved cell proliferation approximately $30 \%$ and $45 \%$, respectively. The control group increased $12 \%$. More cells led to more stimulation of immune cells against antigens. Moreover, both of 19 and $\mathbf{2 0}$ did not bear the innate toxicity towards murine peritoneal macrophages [80].

\subsection{HIV inhibitor}

$\mathrm{hC}_{60} \mathrm{~s}$ inhibited both HIV aspartic protease and HIV reverse transcriptase. Bis(phenethylamincuccinate) $\mathrm{C}_{60}\left(K_{\mathrm{i}}=5.3 \mu \mathrm{M}\right)$ was the first one which reported to bind the large hydrophobic pocket of HIV aspartic protease through van der Waals force [81]. C60-Thr-Tyr-Asn-Thr-Thr inhibited HIV protease as well, but weakly [82]. Furthermore, $\mathrm{C}_{60}$ with amino acid derivatives $\mathbf{2 5}$ and $\mathbf{2 6}$ inhibited HIV reverse transcriptase with $\mathrm{IC}_{50}$ value of $0.029 \mu \mathrm{M}$ and $1.0 \mu \mathrm{M}$, respectively. The activity was better than Nevirapine ${ }^{\circledast}\left(\mathrm{IC}_{50}=3.0 \mu \mathrm{M}\right)$ and $\mathrm{C}_{60}$ with quaternary ammonium salt 2 [83]. Fmoc-Baa $\left(K_{\mathrm{i}}=36 \mathrm{nM}\right)$ had more potent inhibition against HIV aspartic protease than Baa $\left(K_{\mathrm{i}}=120 \mathrm{nM}\right)$. The possible reason was that Fmoc-Baa possessed more hydrogen bonding and van der Waals interaction with HIV aspartic protease [84].

\section{6. $\mathrm{C}_{60}$ containing sugar}

\subsection{Radical scavenger}

$\mathbf{2 7}$ and $\mathbf{2 8}$ were weak radical scavengers (Fig. 5). The large amount of -OH groups maybe induce $\mathrm{C}_{60}$ aggregation and quenched radicals. Both of $\mathbf{2 7}$ and $\mathbf{2 8}$ absorbed the peroxyl radicals. Their activity was comparable with phenolic antioxidant compounds, but weaker than vitamins E and C and $\beta$-carotene [85]. 

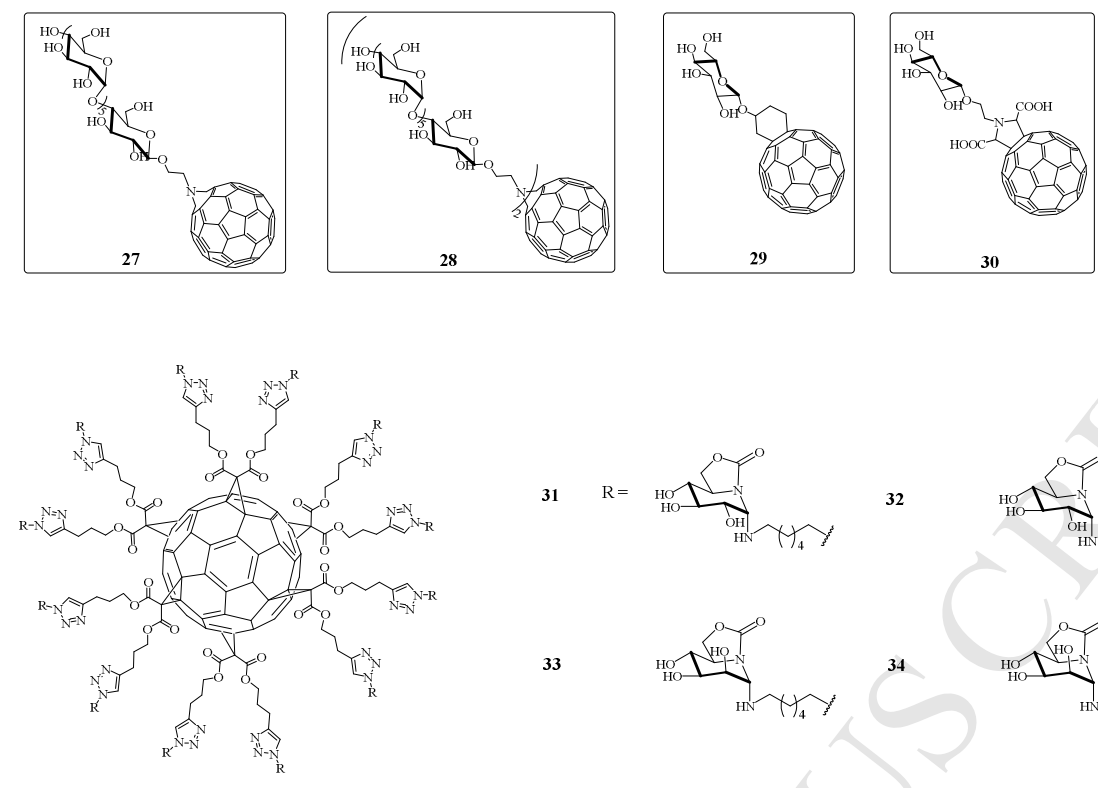
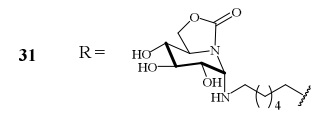

32

33

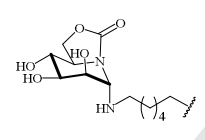

Fig. 5. Representatives of $\mathrm{C}_{60}$ containing sugars

\subsection{ROS producer}

ROS generated by $\mathrm{C}_{60}$-sugar derivatives inhibited HeLa cells and degraded HIV aspartic protease. $\mathrm{C}_{60}$-monosugars produced more ${ }^{1} \mathrm{O}_{2}$ than $\mathrm{C}_{60}$-bissugars. Therefore, $\mathrm{C}_{60}$-monosugars had more potent inhibition against HeLa cells than $\mathrm{C}_{60}$-bissugars under UV exposure [86]. 29 and 30 generated ROS upon the irradiation of both UV and visible light (Fig. 5). ROS led to the degradation of HIV aspartic protease. The photodynamic ability decreased with the co-treatment of DMSO, KI, and histidine, which were $\mathrm{HO} \cdot \mathrm{H}_{2} \mathrm{O}_{2}$ and ${ }^{1} \mathrm{O}_{2}$ scavengers, respectively. $29(1.5 \mu \mathrm{M})$ and $\mathbf{3 0}(15 \mu \mathrm{M})$ induced the complete degradation of HIV aspartic protease. Compared to $29, \mathbf{3 0}$ did not show inhibition against HIV reverse transcriptase. $\mathbf{3 0}$ had the inherent ability against HIV aspartic protease. However, the inhibition without light $\left(\mathrm{IC}_{50}=15.1\right.$ $\mu \mathrm{M})$ was weaker than that $\left(\mathrm{IC}_{50}=2.25 \mu \mathrm{M}\right)$ under irradiation. Moreover, 30 inhibited significantly HIV replication in human leukemic Molt-4 T cells and peripheral blood mononuclear cells. $30(10 \mu \mathrm{M})$ decreased p24 amount (a marker of HIV replication) obviously [87, 88].

\subsection{Drug vector}

$\mathrm{hC}_{60} \mathrm{~s}$ with multiple reactive sites can form multivalent iminosugar systems. Compared to the corresponding monosaccharides analogues with biological activities, $\mathbf{3 1}$, 32, 33 and $\mathbf{3 4}$ loading 12 monosaccharides were more efficient to $\alpha$-mannase, especially, 32 (Fig. 5). However, the corresponding monosaccharide of $\mathbf{3 2}$ had better inhibition than 32 against maltase, isomaltase and $\beta$-glucase. It was attributed to the different shape of the catalytic sites. $\alpha$-mannase possessed the shallow and long active site and allowed several monosaccharides to bind it simultaneously. Therefore, the multivalent $\mathbf{3 2}$ enhanced the inhibition 557-folds compared with the corresponding monosaccharide. On the contrary, other glycosidases, maltase, isomaltase and $\beta$-glucase, bore the deep and narrow active sites. Monosaccharides were more efficient than the multivalent system $[89,90]$. The similar multivalent system, $\mathrm{C}_{60}$ conjugating with 36 mannoses through long linkers, inhibited pseudotyped Ebola virus to enter into cells. Martin N. et al. used the multivalent system with 12 and 24 monosaccharides to block the bacterial adhesion to the cell surface [91, 92].

\section{7. $\mathrm{C}_{60}$ and Cyclodextrins (CDs)}

CDs with inherent hydrophilicity and big cavities are good tools to enhance hydrophilicity of $\mathrm{C}_{60}$. The common derivatives are $\mathrm{C}_{60}-\beta-\mathrm{CD}$ conjugates, $\mathrm{C}_{60} / \beta-\mathrm{CD}$ micelles and $\mathrm{C}_{60} / \gamma-\mathrm{CD}$ complex (Fig 6). $\alpha$-CD was not applied because of the relatively small cavity. All of them are radical producer, serving as DNA cleavage and cells inhibition.

Although $\mathrm{C}_{60}-\beta-\mathrm{CD}$ conjugates aggregated in aqueous solution, they produced ROS under irradiation. ROS destroyed DNA. The mechanism of $\mathrm{C}_{60}$ cleaving DNA was as follows: (1) ${ }^{1} \mathrm{O}_{2}$, produced via Type II Energy Transfer, oxidized the guanosine to 8-Oxo-guanine (8G). It was suggested by the majority; (2) If DNA strands contained guanosine stacks which were liable to oxidation, ${ }^{3} \mathrm{C}_{60} *$ and ${ }^{3} \mathrm{O}_{2}$ accepted the electrons from guanosine (Type I Electron Transfer), successively. $8 \mathrm{G}$ was obtained. The further oxidation of $8 \mathrm{G}$ will generate an alkali-labile site, causing DNA cleavage [93]. 35 was the first reported conjugate to rip DNA. During the cleavage, the characteristic peak $343 \mathrm{~nm}$ of $\mathrm{C}_{60}$ was weakened [94]. 36 was an example that it produced ${ }^{1} \mathrm{O}_{2}$ to destroy DNA [95]. Another $\mathrm{C}_{60}-\beta-\mathrm{CD}$ conjugate 37

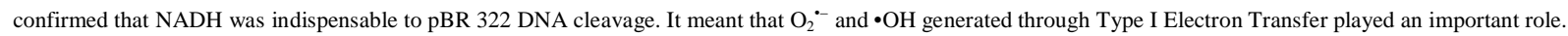


Although $33 \mu \mathrm{mol} \cdot \mathrm{L}^{-1} \mathbf{3 7}$ ripped DNA to small fragments completely, the photodynamic ability to the cells was weak. $400 \mu \mathrm{mol} \cdot \mathrm{L}^{-1} \mathbf{3 7} \mathrm{killed}$ less than $40 \% \mathrm{SH}$ SY5Y cancer cells [96].

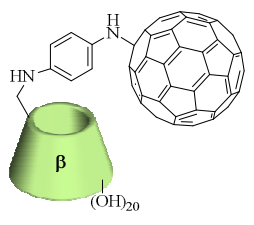

35

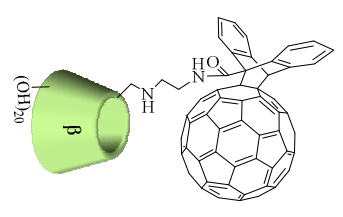

36

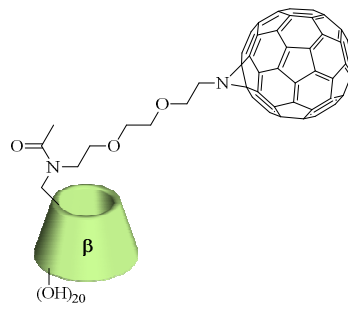

37

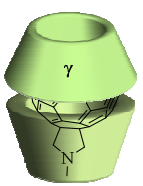

38

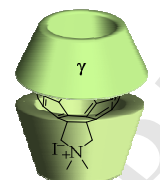

1

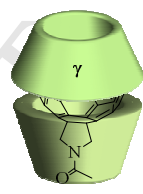

39

Fig. 6. $\mathrm{C}_{60}-\beta-\mathrm{CD}$ conjugates and $\mathrm{C}_{60} \mathrm{~s} / \gamma-\mathrm{CD}$ complexes

$\mathrm{C}_{60} / 2$-hydroxypropyl- $\beta$-CD (HP- $\beta$-CD) nanoparticles produced ROS and killed HeLa cells. The small aggregate led to the effective photodynamic ability because of attenuating the radical self-quenching. Besides, the large $\mathrm{C}_{60}$ aggregate decreased the surface of exposed light, which was possible to lower the efficiency of ROS production [74]. $\mathrm{C}_{60} / \mathrm{HP}-\beta-\mathrm{CD}$ nanoparticle with the size of $90 \mathrm{~nm}$ was obtained by cogrinding $\mathrm{C}_{60}$ and HP- $\beta$-CD for $3 \mathrm{~h}$ at $4{ }^{\circ} \mathrm{C}$ under reduced pressure. $\mathrm{C}_{60} / \mathrm{HP}-\beta-\mathrm{CD}$ colloidal solution was stable and maintained the similar size of aggregate during 28 days. It was more potent to produce ROS than $\mathrm{C}_{60}$ alone solution at the same concentration $(40 \mu \mathrm{M})$. Because the aggregate in $\mathrm{C}_{60}$ alone solution was $427 \mathrm{~nm}$. There was scarcely ${ }^{1} \mathrm{O}_{2}$ production in $\mathrm{C}_{60}$ alone solution, while $\mathrm{C}_{60} / \mathrm{HP}-\beta-\mathrm{CD}$ colloidal solution generated ${ }^{1} \mathrm{O}_{2}, \mathrm{O}_{2}{ }^{--}$and $\bullet \mathrm{OH}$. Hence, $\mathrm{C}_{60} / \mathrm{HP}-\beta-\mathrm{CD}$ colloidal solution $(40 \mu \mathrm{M})$ killed $75 \%$ cancer cells under the visible light irradiation, while $\mathrm{C}_{60}$ alone solution showed no inhibition. Both $\mathrm{C}_{60} / \mathrm{HP}-\beta-\mathrm{CD}$ colloidal solution and $\mathrm{C}_{60}$ alone solution were non-toxic in dark [74].

$\gamma$-CD with a big cavity could encapsulate $\mathrm{C}_{60}$ and avoid aggregation [97]. The cell inhibition was dependent on the ability of ROS production (especially, ${ }^{1} \mathrm{O}_{2}$ ) and cellular uptake. The quantum yield of ${ }^{1} \mathrm{O}_{2}$ generated by $\mathrm{C}_{60} / \gamma-\mathrm{CD}$ complex $(0.78)$ was much higher than that of $\mathrm{C}_{60}(\mathrm{OH})_{24}(0.08)$ in $\mathrm{D}_{2} \mathrm{O}$. $\mathrm{C}_{60} / \gamma-\mathrm{CD}$ complex $\left(\mathrm{IC}_{50}=\right.$ $0.25 \mu \mathrm{M})$ showed higher photodynamic ability than $\mathrm{C}_{60}(\mathrm{OH})_{24}\left(\mathrm{IC}_{50}=15 \mu \mathrm{M}\right)$ against human skin keratinocytes (HaCaT) irradiated with $\mathrm{UVA}\left(15 \mathrm{~J} / \mathrm{cm}^{2}\right)[98]$. The aggregates in $\mathrm{C}_{60} / \gamma$-CD solution increased with heating and no ${ }^{1} \mathrm{O}_{2}$ produced after $150 \mathrm{~min}$. Hence, $2 \mu \mathrm{M} \mathrm{C} \mathrm{C}_{60} / \gamma$-CD complex led to approximately $95 \%$ death of human lens epithelial cells, while $30 \mu \mathrm{M} \mathrm{nC}_{60} / \gamma$-CD aqueous solution (prepared by heating $\mathrm{C}_{60} / \gamma$-CD complex aqueous solution for 150 min) had very low effect. The aggregate in $\mathrm{nC}_{60} / \gamma-\mathrm{CD}$ aqueous solution was $136.6 \mathrm{~nm}$ [99]. Although $\mathrm{C}_{60} / \gamma-\mathrm{CD}$ complex was absorbed into cells much more slowly than $\mathrm{C}_{60}(\mathrm{OH})_{24}$ and $\mathrm{nC}_{60} / \gamma-\mathrm{CD}$, it showed the most potent inhibition $[98,99]$. However, $\mathrm{C}_{60} / \gamma-\mathrm{CD}$ complex did not have strong inhibition against HeLa cells. $10 \mu \mathrm{M} \mathrm{C}_{60} / \gamma-\mathrm{CD}$ had negligible effect either in dark or under $400-500 \mathrm{~nm}$ irradiation. $\mathrm{C}_{60} / 6$-amino- $\gamma-\mathrm{CD}(10 \mu \mathrm{M})$ caused more than $60 \%$ HeLa cell death under irradiation. The intriguing phenomenon was that $\mathrm{C}_{60} / 6$-amino- $\gamma$-CD could squeeze $\mathrm{C}_{60}$ out when $\mathrm{pH}$ was lowered from 7.4 to 6.4. It possessed stronger inhibition at $\mathrm{pH}=6.4$ than that at $\mathrm{pH}=7.4$, although there was colloidal aggregates in the solution with $\mathrm{pH}=6.4$. The size of colloidal aggregate was small, only $20 \mathrm{~nm}$. It was possible that the small $\mathrm{C}_{60}$ aggregates were absorbed by HeLa cells faster than $\mathrm{C}_{60} / 6$-amino- $\gamma-\mathrm{CD}$ and $\mathrm{C}_{60} / \gamma-\mathrm{CD}[100]$.

The pristine $\mathrm{C}_{60}$ can not absorb the long wavelength light $(610-740 \mathrm{~nm})$, but the functinalized $\mathrm{C}_{60}$ derivatives could generate ${ }^{1} \mathrm{O}_{2}$ under this range of irradiation. The photodynamic ability against HeLa cells was $\mathbf{1} / \gamma$-CD complex $\left(\mathrm{IC}_{50}=0.47 \mu \mathrm{M}\right)>\mathbf{3 9} / \gamma-\mathrm{CD}$ complex $\left(\mathrm{IC}_{50}=0.95 \mu \mathrm{M}\right) \gg \mathbf{3 8} / \gamma-\mathrm{CD}$ complex $\approx \mathrm{C}_{60} / \gamma-\mathrm{CD}$ complex. The clinical photosensitizer Photofrin inhibited HeLa cells with $\mathrm{IC}_{50}=2 \mu \mathrm{M}$. The photodynamic activity decreased with the co-treatment of ${ }^{1} \mathrm{O}_{2}$ quencher ${ }^{\mathrm{L}}$-histidine, while the addition of D-mannitol $\left(\mathrm{O}_{2}{ }^{-}\right.$quencher) did not lower cell viability. 38/ $\gamma$-CD complex was a weak photosensitizer attributed to electron-transfer quenching caused by the long pair electrons on the amine. ${ }^{3} \mathrm{C}_{60} *$ of $\mathbf{3 8} / \gamma$-CD complex was quenched before it produced ${ }^{1} \mathrm{O}_{2}$ via energy transfer. 39/ $\gamma$-CD complex with the - Ac on amine weakened the quenching effect. Cationic $\mathbf{1} / \gamma$-CD complex had the best inhibition owing to the electrostatic interaction with the anionic surface of HeLa cells [101].

\section{C 60 delivered by liposomes}

\subsection{ROS producer}

Lipid membrane-incorporated $\mathrm{C}_{60}\left(\mathrm{LMIC}_{60}\right)$ was more stable than $\gamma$-CD/C 60 complex in water. $\mathrm{LMIC}_{60}$ was obtained via an exchange reaction between liposomes and $\gamma-\mathrm{CD} / \mathrm{C}_{60}$ complex by three methods, which were heating, microwave irradiation and photoinduced electron transfer [102, 103]. $\mathrm{C}_{60}$ was released from $\gamma-\mathrm{CD}$ and encased into liposomes. Because the peak assignable to $\gamma-\mathrm{CD} / \mathrm{C}_{60}$ complex at 4.19 and $5.05 \mathrm{ppm}$ diappeared. Under the exposure of visible light, cationic $\mathbf{4 0 -}$ incorporated $\mathrm{C}_{60}$ showed $44 \%$ DNA cleavage and zwitterionic 41-incorporated $\mathrm{C}_{60}$ converted $24 \%$ supercoiled DNA (form I) to nicked DNA (form II) at the same concentration of $20 \mu \mathrm{M}$. Anionic 42-incorporated $\mathrm{C}_{60}(20 \mu \mathrm{M})$ had little DNA cleaving ability (just $2 \%$ ), even lower than $20 \mu \mathrm{M} \gamma$-CD/C 60 complex $(6 \%)$. It was attributed to the electrostatic repulsions between 'anionic' 42-incorporated $\mathrm{C}_{60}$ and 'anionic' DNA [104]. 
Cationic $\mathrm{LMIC}_{60}$ had stronger inhibition against HeLa cells than anionic $\mathrm{LMIC}_{60}$ [105]. Because cationic 43 -incorporated $\mathrm{C}_{60}$ was relatively easier to bind to the anionic cellular surface and engendered cell death [133]. LMIC $_{60} \mathbf{4 3 + 4 1}$ led to the morphological change of cells and 85\% cells were killed, while $1 \%$ cells were dead with the treatment of $\mathrm{LMIC}_{60} \mathbf{4 2 + 4 1}$ under 350-500 $\mathrm{nm}$ exposure [105]. Zwitterionic liposome $\mathbf{4 1}$ was used as matrix here.

Compared to $\mathrm{LMIC}_{60}$, the block copolymer micelle-incorporated $\mathrm{C}_{60} \mathrm{~s}\left(\mathrm{BPMIC}_{60} \mathrm{~s}\right.$ ) aqueous solution were more stable [106]. Cationic BPMIC 60 was absorbed by cells, while anionic and neutral BPMIC $_{60}$ can not. BPMIC $_{60} 45$ with the proper feed ratio of the fragments (n:p = 53:47) possessed the best water-solubility and photodynamic ability. It induced $98.7 \%$ HeLa cells death under 350-500 nm irradiation. No cytotoxicity was observed in dark.

\subsection{Radical scavenger}

Depending on low dispersion of $\mathrm{C}_{60}, \mathrm{C}_{60}$ solubilized by hydrogenated lecithin $\mathbf{4 6}$ and glycine soja sterols was as ROS scavenger. $\mathrm{C}_{60} / \mathbf{4 6} / \mathrm{sterol}$ reduced ROS generation and improved the cell viability of HaCaT cells under $10 \mathrm{~J} / \mathrm{cm}^{2}$ UVA exposure [107]. It repressed the striated skin surface, abnormal scaling of epidermis and dermis. $\mathrm{C}_{60} / \mathbf{4 6} /$ sterol $(0.63 \mu \mathrm{M})$ suppressed the abnormality of nucleus, such as, condensed chromatin and shrunken nucleus. $\mathrm{C}_{60} / \mathbf{4 6} /$ sterol was nontoxic to the normal tissues. It penetrated into the epidermis and can not arrive at the dermis [108].

$\mathrm{C}_{60} / \mathbf{4 6}$ inhibited influenza virus (H1N1) in vivo, which was possibly relate to ROS scavenging [109]. The average mice survival was $\mathrm{C}_{60} / \mathbf{4 6}(3.3 \mathrm{mg} / \mathrm{kg} / \mathrm{day})>\mathrm{C}_{60} / \mathbf{4 6}$ $(1.6 \mathrm{mg} / \mathrm{kg} /$ day $) \approx$ rimantadine $(90 \mathrm{mg} / \mathrm{kg} /$ day $)>\mathrm{C}_{60} / \mathbf{4 6}(0.8 \mathrm{mg} / \mathrm{kg} /$ day $) \gg$ the control without administration. The mice treated with $\mathrm{C}_{60} / \mathbf{4 6}(3.3 \mathrm{mg} / \mathrm{kg} / \mathrm{day}) \mathrm{survived}$ for 16 days, which was longer than 9 days of the control group. The viral yield decreased from 19.3 to 8.6 with the administration of $\mathrm{C}_{60} / \mathbf{4 6}$ ( $3.3 \mathrm{mg} / \mathrm{kg} / \mathrm{day}$ ), which was same level as rimantadine. The co-treatment with both $\mathrm{C}_{60} / \mathbf{4 6}$ and rimantadine lowered the lung index to the normal level as the control group [109].

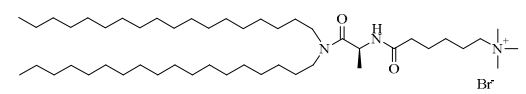

40

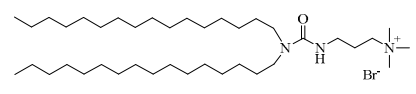

43

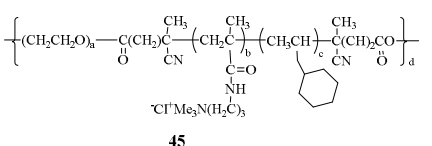

45
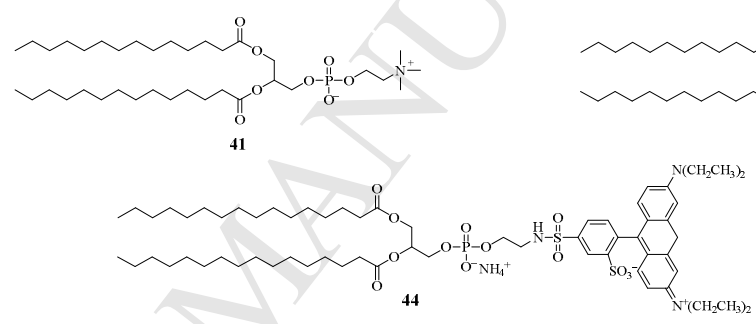

min.

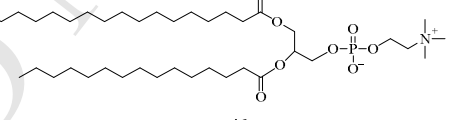

Fig. 7. Common Liposomes as $\mathrm{C}_{60}$ Solubilizer

\section{9. $\mathrm{C}_{60}$ and polymers}

\subsection{Radical scavenger}

$\mathrm{C}_{60} / \mathrm{PNVP}$ was Radical Sponge ${ }^{\circledast}$. It protected HaCaT cells from the oxidative damage induced by UVB and $t$-BuOOH [110]. Besides, $\mathrm{C}_{60} / \mathrm{PNVP}$ decreased UVAinduced ROS level in normal human epidermis melanocytes. The effect was not dose-dependent. Compared to Radical Sponge ${ }^{\circledR}$ at $75 \mu \mathrm{M}$, the lower concentration (25 $\mu \mathrm{M}$ ) engendered higher ROS inhibition. $68 \%$ intracellular ROS was reduced in human malignant melanoma cell line. With the treatment of $50 \mu \mathrm{M}$ Radical Sponge ${ }^{\circledR}$, the melanin content induced by $0.1 \mathrm{~J} / \mathrm{cm}^{2}$ UVA reduced from $190 \%$ to $54.6 \%$ and tyrosinase activity lowered from $136 \%$ to $50 \%$. Radical Sponge ${ }^{\circledR}$ was more effective than arbutin (a tyrosinase inhibitor, preventing the formation of melanin) and L-ascorbic acid (an antioxidant agent) at $500 \mu \mathrm{M}$ [111]. Another study showed that $\mathrm{C}_{60} /$ squalene (a skin emollient) localized in the epidermis and did not penetrate into the dermis. The location of $\mathrm{C}_{60} / \mathrm{squalene}$ was consistent with $\mathrm{C}_{60} / \mathbf{4 6} / \mathrm{sterol}$ [112].

Although PEG/ $\mathrm{C}_{60}$ was not efficient as $\mathrm{C}_{60} / \mathrm{PNVP}, \mathrm{C}_{60}$-PEG was a good radical scavenger and delivery [110, 113]. 47 and $\mathbf{4 8}$ decreased the innate toxicity of DOX attributed to the ability of radical scavenging and slow-release of DOX (Fig. 9). The urethane bonds linking DOX and $\mathrm{C}_{60}-\mathrm{PEG}$ were degraded in vivo. Both $\mathbf{4 7}$ and $\mathbf{4 8}$ possessed no antineoplastic effect against MCF-7 cells at the concentration less than $1.5 \mu \mathrm{M}$, while free DOX reduced cell viability to $40 \%$ at the same concentration. Because of the slow cellular uptake, $\mathbf{4 7}$ and $\mathbf{4 8}$ did not show stronger inhibition than DOX alone until $72 \mathrm{~h}$. Free DOX entered into the nucleus after 15 min, while $\mathbf{4 7}$ and $\mathbf{4 8}$ were localized in the nucleus after 72h. Both of $\mathbf{4 7}$ and $\mathbf{4 8}$ formed aggregation in water, which were $143 \mathrm{~nm}$ and $147 \mathrm{~nm}$ [113].

$\mathrm{C}_{60}$-PNIPAM copolymer with large aggregates $(1000 \mathrm{~nm})$ was a radical scavenger as well. It $\left(1.25 \mathrm{mg} \mathrm{mL}^{-1}\right)$ enhanced the fibroblasts viability inherently and prevented the oxidative damage from NOR-3 (NO-- producer) [114]. 


\subsection{ROS producer}

\subsection{1 $\mathrm{C}_{60}$ and PNVP}

Radical polymerization is a common method to produce $\mathrm{C}_{60}-\mathrm{PNVP}$ copolymer (Fig.8). On one hand, the copolymerization of $\mathrm{C}_{60}$ and $N$-vinylpyrrolidone (NVP) was carried out directly with 2,2'-azobisisobutyronitrile (AIBN, a radical initiator) (Fig. 8) [115, 116]. On the other hand, PNVP linked to $\mathrm{C}_{60}$ through PVAc via cobaltmediated radical polymerization (CMRP). 2,2'-azobis(4-methoxy-2,4-dimethyl valeronitrile) (V-70) served as a radical generator, PNVP-co-PVAc-cobalt(II) acetylacetonate $\left(\mathrm{Co}(\mathrm{acac})_{2}\right)$ was prepared and reacted with $\mathrm{C}_{60}$ (Fig. 8) [117, 118].

A:

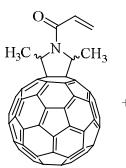

$\sum_{\text {NVP }}^{W^{N}}$

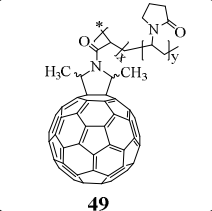

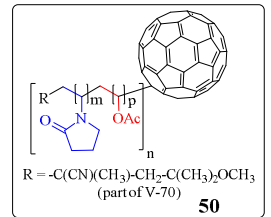
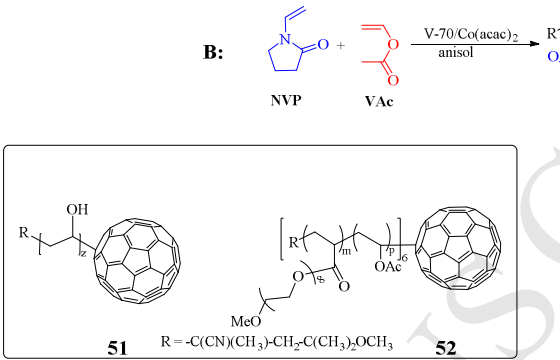

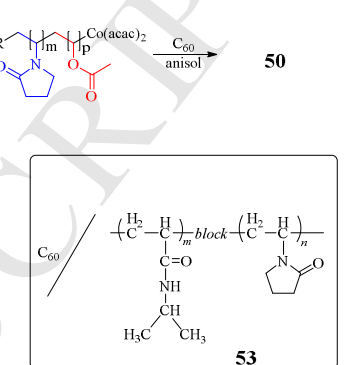

Fig. 8. Synthesis of $\mathrm{C}_{60}-\mathrm{PNVP}$ copolymers and Representatives

$\mathrm{C}_{60}-\mathrm{PNVP}$ copolymer 49 and PNVP-co-PVAc copolymer $\mathbf{5 0}$ were photosensitizers to cleave DNA and kill cells in vitro, respectively. 49 produced $\mathrm{O}_{2}{ }^{-}$under the irradiation of visible light, while ${ }^{1} \mathrm{O}_{2}$ was the main ROS generated by $\mathbf{5 0} . \mathrm{C}_{60}$-PNVP copolymer $\mathbf{4 9}$ (the feed radio of $\mathrm{C}_{60}$ : NVP = 1:200) showed the highest watersolubility $\left(7.8 \mathrm{mM}\right.$, calculated by $\mathrm{C}_{60}$ ). The particle size of 49 in water was $19.5 \mathrm{~nm} . \mathbf{4 9}$ had the molecular weight of $39 \mathrm{kDa}$, which was more than $20 \mathrm{kDa}$, accumulated selectively in tumor cells owing to EPR effect [119]. 49 (1 mM, calculated by $\mathrm{C}_{60}$ ) cleaved pBR322 DNA (Form I) to nicked form II in the presence of $10 \mathrm{mM}$ of $\mathrm{NADH}$ under irradiation of visible light [115]. On the contrary, no $\mathrm{O}_{2}^{-{ }^{-}}$was produced by $\mathbf{5 0}$ [80]. $\mathbf{5 0}$ at the concentration of $58 \mu \mathrm{M}$ produced comparative amount of ${ }^{1} \mathrm{O}_{2}$ with a common photosensitizer, 4,4',4", 4, ' -(porphine-5,10,15,20-tetrayl)tetrakis(benzenesulfonic acid) (TPPS, 5.5 $\left.\mu \mathrm{M}\right)$ [117]. Moreover, $\mathbf{5 0}$ decreased

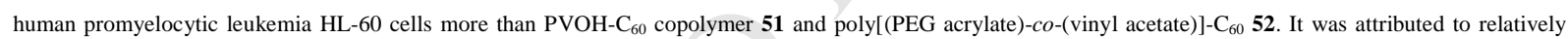
high ${ }^{1} \mathrm{O}_{2}$ quantum yield of $\mathbf{5 0}\left(\Phi\left({ }^{1} \mathrm{O}_{2}\right)=0.50\right)$, compared to that of $\mathbf{5 1}\left(\Phi\left({ }^{1} \mathrm{O}_{2}\right)=0.12\right)$ and $\mathbf{5 2}\left(\Phi\left({ }^{1} \mathrm{O}_{2}\right)=0.13\right)[120]$. Another ${ }^{1} \mathrm{O}_{2}$ producer, $\mathrm{C}_{60} / \mathrm{PNIPAM}_{\mathrm{m}}-b-\mathrm{PNVP}_{\mathrm{n}}$ micelle $\mathbf{5 3}$ had the DNA-cleaving effect as well [121].

\subsection{2 $\mathrm{C}_{60}$ and PEG}

The well-dispersed $\mathrm{C}_{60}$-PEG derivatives were innate photosensitizers (Fig. 9). This ability was extended in combination with other biologically effective agents. Although $\mathrm{C}_{60}$-PEG 54 had interaction with $\mathrm{A} \beta_{42}\left(\mathrm{IC}_{50}=192 \mu \mathrm{M}\right)$, the affinity of monosaccride-PEG-C 6055 was stronger $\left(\mathrm{IC}_{50}=35 \mu \mathrm{M}\right)$. The binding ability was enhanced to $\mathrm{IC}_{50}=2 \mu \mathrm{M}$ under $365 \mathrm{~nm}$ irradiation. Both $\mathrm{A} \beta_{42}$ monomer and oligomer were degraded by $\mathbf{5 5}$ upon $\mathrm{UV}$ exposure because of $\mathrm{O}_{2}{ }^{-}$and $\mathrm{OH} \bullet$ generation [122]. Another example was that $\mathrm{C}_{60}$-iron oxide nanoparticle (INOP)-PEG/hematoporphyrin monomethyl ether (HMME) 56 produced more ROS than $\mathrm{C}_{60}$-INOP-PEG and HMME under the exposure of $532 \mathrm{~nm}$ laser. The relative tumor volume of $\mathrm{C}_{60}$-INOP-PEG-treated $\left(V / V_{0}=5.96 \pm 0.79\right)$ and $\mathrm{HMME}$-treated $\left(V / V_{0}=6.45 \pm 0.81\right)$ mice increased more obviously than 56-treated group $\left(V / V_{0}=2.72 \pm 0.55\right)$ [123]. The further studies applied magnetic resonance imaging agents Gd-DTPA to enhance the efficiency of $\mathrm{C}_{60}$. Gd-DTPA-PEG- $\mathrm{C}_{60}$ had the similar level of $\mathrm{O}_{2}{ }^{-}$production and reducing cell viability (40\%) with the irradiation of visible light compared to $\mathrm{C}_{60}$-PEG. The $R_{l}$ relaxivity of Gd-DTPA-PEG-C $\left.60.3 \mathrm{mM}^{-1} \mathrm{~s}^{-1}\right)$ was comparable with Magnevist ${ }^{\circledast}\left(5.3 \mathrm{mM}^{-1} \mathrm{~s}^{-1}\right)$. Both of them enhanced MRI signal intensity in tumor, but Gd-DTPA-PEG-C 60 maintained in the tumor tissues much longer in a relatively high level than Magnevist ${ }^{\circledR}$ [124]. Except Gd-DTPA, Fe $\mathrm{O}_{4}$ visualized the tumor tissues as well. $\mathrm{C}_{60}-\mathrm{Fe}_{3} \mathrm{O}_{4}-\mathrm{PEG}_{2000}$ /docetaxel-thermosensitive liposome was a negative $\left(T_{2}\right)$ contrast agent. Besides, this particle released docetaxel and $\mathrm{C}_{60}{ }^{-}$ $\mathrm{Fe}_{3} \mathrm{O}_{4}-\mathrm{PEG}_{2000}$ after the increasing temperature of tumor issues by $13.56 \mathrm{MHz}$. radiofrequency. The radiofrequency also led to ROS generation. ROS assisted docetaxel to inhibit MCF-7 tumor cells [125].

$\mathrm{C}_{60}$ has the highest absorption under UV. However, UV can not penetrate the skin. Therefore, the agents absorbing the light with long wavelength (> $\left.620 \mathrm{~nm}\right)$ were utilized. The photodynamic activity was improved when $\mathrm{C}_{60}$-PEGs conjugated with graphene oxide (GO), chlorin e6 (Ce6), and upconversion nanoparticles (UCNP). Among these conjugates, FA was introduced to target tumor cells.

FA-GO-PEG- $\mathrm{C}_{60}$ had a synergistic effect on antineoplastic therapy. $\mathrm{GO}$ absorbed the energy from $808 \mathrm{~nm}$ and released vibrational heat. $\mathrm{C}_{60}$ produced ${ }^{1} \mathrm{O}_{2}$ under the irradiation of $532 \mathrm{~nm}$. Both of the released heat and ROS inhibited HeLa cells. The combination of $808 \mathrm{~nm}$ and $532 \mathrm{~nm}$ exposures led to the cell viability of $3.1 \%$ after 
treated with FA-GO-PEG-C $60(10 \mu \mathrm{g} / \mathrm{mL})$. GO lowed the cell viability to $80.4 \%$ after $808 \mathrm{~nm}$ exposure and FA-C 60 decreased the cell survival to $72.4 \%$ with $532 \mathrm{~nm}$ irradiation. The cellular uptake to FA-GO-PEG-C 60 was stronger than GO and FA-GO [126].
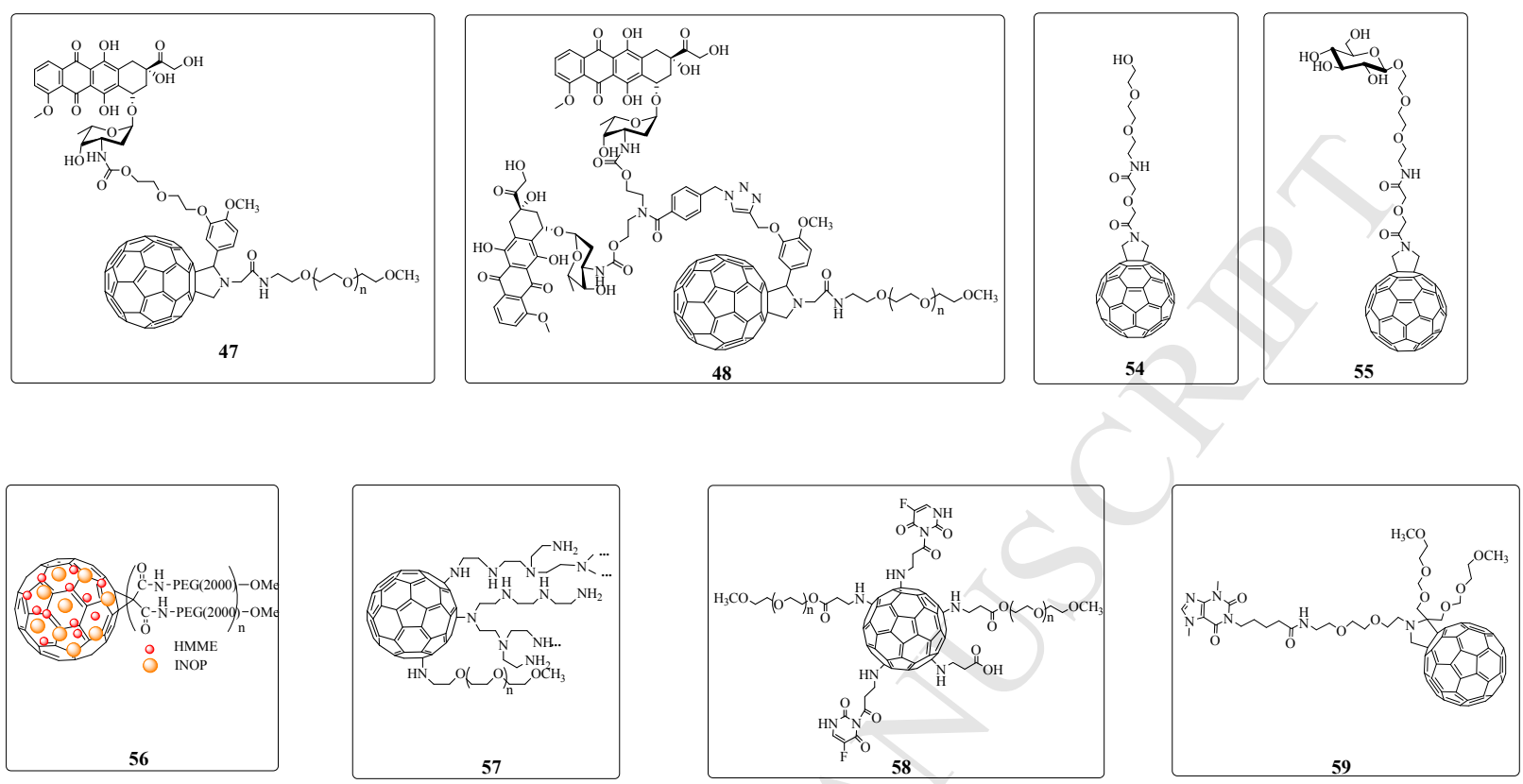

Fig.9. $\mathrm{C}_{60}$-PEGs

Ce6-PEG-C ${ }_{60}$-PEG-FA had both photothermal and photodynamic ability, led to the inhibition of human nasopharyngeal epidermal carcinoma KB tumor and arthritic progress. The photosensitizer Ce6 got energy from $670 \mathrm{~nm}$ and provided the photon to $\mathrm{C}_{60}$. Under $670 \mathrm{~nm}$ irradiation for 7 days, Ce6-PEG-C 60 -PEG-FA kept the tumor volume at the same level (from $47 \mathrm{~mm}^{3}$ to $54 \mathrm{~mm}^{3}$ ), while the tumor volume treated by $\mathrm{C}_{60}$-PEG-FA increased from $58 \mathrm{~mm}^{3}$ to $150 \mathrm{~mm}^{3}$. Besides, the arthritic foot surface temperature of the mice increased to $45^{\circ} \mathrm{C}$ after $2 \mathrm{~h}$ injection. The generated ROS efficiently inhibited arthritic progress after 5 days irradiation [127].

UCNPs transferred the photon to $\mathrm{C}_{60}(\mathrm{COOH})_{2}$ upon the exposure of near-infrared light (NIR, $\sim 980 \mathrm{~nm}$ ). PEG-succinimidyl carbonate (SC)-UCNPs- $\mathrm{C}_{60}(\mathrm{COOH})_{2}$ possessed better solubility in water. The particles generated ROS. The phototoxicity to HeLa cells was dose-dependent and the inhibition was obvious at the concentration of $800 \mu \mathrm{M}$ with the exposure of $980 \mathrm{~nm}$ (the cell viability <30\%). On the contrary, PEG-SC-UCNPs- $\mathrm{C}_{60}(\mathrm{COOH})_{2}$ had a lower toxicity without $980 \mathrm{~nm}$ irradiation (approximately $90 \%$ of the cell viability). Besides, UCNPs emitted multicolor in the visible spectral region, which was applied on NIR imaging [128].

\subsection{Drug delivery}

As a biocompatible linker, $\mathrm{C}_{60}$-PEGs enhanced the bioavailability of polyethyleneimine (PEI), 5-fluorouracil (5-FU), doxorubicin (DOX) and pentoxifylline (PTX). The introduction of $\mathrm{C}_{60}$-PEG balanced the toxicity and transfection efficiency of PEI. $\mathrm{C}_{60}$-PEG-PEI 57 was as DNA vector. $\mathrm{C}_{60}$-PEI and free PEI blocked the cell proliferation, while the cell amount increased to twice with the incubation of $\mathbf{5 7}$. More cells meant more expression of enhanced yellow-green Aequorea victoria fluorescent protein (EYFP). This compensated the effect that $\mathbf{5 7}$ was less efficient vehicle than $\mathrm{C}_{60}$-PEI. Because the efficiency of $\mathbf{5 7}$ transporting pEYFP-C1 plasmid at the N/P ratio above 60 was comparable with that of $\mathrm{C}_{60}-\mathrm{PEI} / \mathrm{pEYFP}(\mathrm{N} / \mathrm{P}$ ratio $=20)$ [129]. Other examples showed that $\mathrm{C}_{60}-\mathrm{PEGs}$ improved effective dosage of 5 $\mathrm{FU}$ and PTX. The retention time of 5-FU-PEG-C 605 was longer than free 5-FU in vivo. Because $\mathrm{C}_{60}$-PEG protected 5-FU from the degradation by dihydropyrimidine dehydrogenase. $\mathbf{5 8}$ released 5-FU slowly to cells and liver. 30\% MCT-7 cells were inhibited with the incubation of $\mathbf{5 8}$ at $3.8 \mu \mathrm{M}$, while 5-FU at the same concentration inhibited less than $10 \%$ cells [130]. $\mathrm{C}_{60}$-PEG facilitated PTX to pass through the blood-brain barrier attributed to the mechanism of disruption of the tight junctions of brain microvessel endothelial cells [131]. The cell decreased to $67.9 \%$ owing to the suffering of A $\beta_{25-35}$. PTX-PEG-C 60 enhanced the cell viability to $82.7 \%$, which was more potent than PTX (71.0\%) [132].

\section{Conclusion}

The main applications of $\mathrm{hC}_{60} \mathrm{~s}$ are radical scavenger and $\mathrm{ROS}$ producer. Although each $\mathrm{hC}_{60}$ derivative has the potential to be both, they show a preference. $\mathrm{h} \mathrm{C}_{60}$

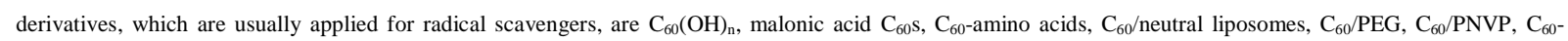
PNIPAM. ROS producers are $\mathrm{C}_{60}$ with quaternary ammonium salts, $\mathrm{C}_{60}$ containing sugars, $\mathrm{C}_{60} /$ peptide, $\mathrm{C}_{60}-\beta$-CD conjugates, $\mathrm{C}_{60} / \gamma-\mathrm{CD}$ complex, $\mathrm{C}_{60} /$ cationic 
liposomes, $\mathrm{C}_{60}$-PNVP copolymer, PNVP-co-PVAc copolymer and $\mathrm{C}_{60}$-PEGs. To our knowledge, the preference is dependent to the extent of dispersion. $\mathrm{hC} 6{ }_{60} \mathrm{~S}$ as $\mathrm{ROS}^{-}$ producer form less aggregates than radical scavenger. The aggregates in aqueous solution will decrease ROS production (1.3 Pristine $\mathbf{C}_{60}$ and $\left.\mathbf{h} \mathbf{C}_{60} \mathbf{s}\right)$. The low dispersion leads to radical scavenging, such as fullerenol and $\mathrm{C}_{60} / \mathrm{PNVP}$ (Radical Sponge ${ }^{\circledR}$ ). Furthermore, $\mathrm{C}_{60}$ with quaternary ammonium salts inhibit $\mathrm{O}_{2}$ uptake. $\mathrm{C}_{60^{-}}$ amino acids are HIV inhibitor. $\mathrm{C}_{60}$ with quaternary ammonium salts, $\mathrm{C}_{60}$-amino acids, $\mathrm{C}_{60}$-multivalent iminosugars, $\mathrm{C}_{60}$-PEGs are good vectors for DNA or drugs.

\section{Acknowledgments}

We thank the China Scholarship Council CSC) for a Ph.D. fellowship to Xiaolei Zhu. Financial supports from the Centre National de la Recherche Scientifique (CNRS) and the Université Pierre et Marie Curie (UPMC) are gratefully acknowledged.

\section{References:}

[1] H.W. Kroto, J.R. Heath, S.C. O’Brien, R.F. Curl, R.E. Smalley, C60 : Buckminsterfullerene, Nature 318 (1985) 162-163.

[2] W. Krätschmer, L.D. Lamb, K. Fostiropoulos, D.R. Huffman, Solid C60: a new form of carbon, Nature 347 (1990) 354-358.

[3] J.B. Howard, J.T. McKinnon, Y. Makarovsky, A.L. Lafleur, M.E. Johnson, Fullerene C$_{60}$ and C $_{70}$ in flames, Nature 352 (1991) $139-141$.

[4] N. Komatsu, T. Ohe, K. Matsushige, A highly improved method for purification of fullerenes applicable to large-scale production, Carbon 42 (2004) $163-167$.

[5] R.E. Smalley, Self-Assembly of the Fullerenes, Acc. Chem. Res. 25 (1992) 98-105.

[6] J.Y. Huang, F. Ding, K. Jiao, B.I. Yakobson, Real time microscopy, kinetics, and mechanism of giant fullerene evaporation, Phys. Rev. Lett. 99 (2007) 175503-1$175503-4$.

[7] T.C. Dinadayalane, J. Leszczynski, Remarkable diversity of carbon-carbon bonds: structures and properties of fullerenes, carbon nanotubes, and grapheme, Struct. Chem. 21 (2010) 1155-1169.

[8] D.E. Manolopoulos, P.W. Fowler, Molecular graphs, point groups, and fullerene, J. Chem. Phys. 96 (1992) 7603-7614.

[9] R.C. Haddon, L.E. Brus, K. Raghavachari, Electronic structure and bonding in icosahedral C60, Chem. Phys. Lett. 125 (1986) $459-464$.

[10] X. Lu, Z.F. Chen, Curved Pi-Conjugation, Aromaticity, and the Related Chemistry of Small Fullerenes (<C60) and Single-Walled Carbon Nanotubes, Chem. Rev. 105 (2005) 3643-3696.

[11] I. Fernández, M. Solà, F.M. Bickelhaupt, Why Do Cycloaddition Reactions Involving C60 Prefer [6,6] over [5,6] Bonds? Chem. Eur. J. 19 (2013) $7416-7422$.

[12] C. Bingel, Cyclopropylation of Fullerenes, Chem. Ber. 126 (1993) 1957-1959.

[13] A. Bolag, J. López-Andarias, S. Lascano, S. Soleimanpour, C. Atienza, N. Sakai, N. Martín, S. Matile, A Collection of Fullerenes for Synthetic Access Toward Oriented Charge-Transfer Cascades in Triple-Channel Photosystems, Angew. Chem. Int. Ed. 53 (2014) 4890-4895.

[14] J. Iehl, F. Nierengarten, A Click-Click Approach for the Preparation of Functionalized [5:1]-Hexaadducts of C60, Chem. Eur. J. 15 (2009) 7306-7309.

[15] Y. Cao, Y. Liang, L. Zhang, S. Osuna, A.M. Hoyt, A.L. Briseno, K.N. Houk, Why Bistetracenes Are Much Less Reactive Than Pentacenes in Diels-Alder Reactions with Fullerenes, J. Am. Chem. Soc. 136 (2014) 10743-10751.

[16] T.E. Shubina, D.I. Sharapa, C. Schubert, D. Zahn, M. Halik, P.A. Keller, S.G. Pyne, S. Jennepalli, D.M. Guldi, T. Clark, Fullerene Van der Waals Oligomers as Electron Traps, J. Am. Chem. Soc. 136 (2014) 10890-10893.

[17] S.H. Lim, J. Yi, G.M. Moon, C.S. Ra, K. Nahm, D.W. Cho, K. Kim, T.G. Hyung, U.C. Yoon, G.Y. Lee, S. Kim, J. Kim, P.S. Mariano, Method for the synthesis of amine-functionalized fullerenes involving SET-promoted photoaddition reactions of $\alpha$-silylamines, J. Org. Chem. 79 (2014) 6946-6958.

[18] H. Li, C. Risko, J.H. Seo, C. Campbell, G. Wu, J.L. Brédas, G.C. Bazan. Fullerene-carbene Lewis acid-base adducts, J. Am. Chem. Soc. 133 (2011) 1241012413. 
[19] Y. Li, L. Gan, Selective Addition of Secondary Amines to C60: Formation of Penta- and Hexaamino[60]fullerenes, J. Org. Chem. 79 (2014) $8912-8916$.

[20] Y. Xiao, S.E. Zhu, D.J. Liu, M. Suzuki, X. Lu, G.W. Wang, Regioselective electrosynthesis of rare 1,2,3,16-functionalized [60]fullerene derivatives, Angew. Chem. Int. Ed. Engl. 53 (2014) 3006-3010.

[21] L. Echegoyen, L.E. Echegoyen, Electrochemistry of Fullerenes and Their Derivatives, Acc. Chem. Res. 31 (1998) 593-601.

[22] J.W. Arbogast, A.P. Darmanyan, C.S. Foote, Y. Rubin, F.N. Diederich, M.M. Alvarez, S.J. Anz, R.L. Whetten, Photophysical Properties of C 60 , J . Phys. Chem. 95 (1991) 11-12.

[23] J. Lee, Y. Yamakoshi, J.B. Hughes, J.H. Kim, Mechanism of C60 photoreactivity in water: fate of triplet state and radical anion and production of reactive oxygen species, Environ. Sci. Technol. 42 (2008) 3459-3464.

[24] S. Perni, P. Prokopovich, J. Pratten, I.P. Parkin, M. Wilson, Nanoparticles: their potential use in antibacterial photodynamictherapy, Photochem. Photobiol. Sci. 10 (2011) 712-720.

[25] M. Lens, L. Medenica, U. Citernesi, Antioxidative capacity of C60 (buckminsterfullerene) and newly synthesized fulleropyrrolidine derivatives encapsulated in liposome, Biotechnol. Appl. Biochem. 51 (2008) 135-140.

[26] J. Lee, Y. Yamakoshi, J.B. Hughes, J-H. Kim, Mechanism of $\mathrm{C}_{60}$ photoreactivity in water: fate of triplet state and radical anion and production of reactive oxygen species, Environ. Sci. Technol. 42 (2008) 3459-3464.

[27] L.Y. Chiang, R.B. Upasani, J.W. Swirczewski, S. Soled, Evidence of Hemiketals Incorporated in the Structure of Fullerols Derived from Aqueous Acid Chemistry, J. Am. Chem. Soc. 115 (1993) 5453-5457.

[28] H.M. Huang, H.C. Ou, S.J. Hsieh, L.Y. Chiang, Blockage of amyloid beta peptide-induced cytosolic free calcium by fullerenol-1, carboxylate C60 in PC12 cells, Life Sci. 66 (2000) 1525-1533.

[29] V. Djordjević, A. Djordjević, S. Dobrić, R. Injac, D. Vučković, K. Stankov, V. Dragojević, L.J. Suvajdžić, Influence of Fullerenol C60(OH)24 on Doxorubicin Induced Cardiotoxicity in Rats, Mater. Sci. Forum 518 (2006) 525-529.

[30] R. Injac, M. Boskovic, M. Perse, E. Koprivec-Furlan, A. Cerar, A. Djordjevic, B. Strukelj, Acute doxorubicin nephrotoxicity in rats with malignant neoplasm can be successfully treated with fullerenol $\mathrm{C} 60(\mathrm{OH}) 24$ via suppression of oxidative stress, Pharmacol. Rep. 60 (2008) 742-749.

[31] R. Injac, N. Radic, B. Govedarica, M. Perse, A. Cerar, A. Djordjevic, B. Strukelj, Acute doxorubicin pulmotoxicity in rats with malignant neoplasm is effectively treated with fullerenol $\mathrm{C} 60(\mathrm{OH}) 24$ through inhibition of oxidative stress, Pharmacol. Rep. 61 (2009) 335-342.

[32] R. Injac, M. Perse, N. Obermajer, V. Djordjevic-Milic, M. Prijatelj, A. Djordjevic, A. Cerar, B. Strukelj, Potential hepatoprotective effects of fullerenol $\mathrm{C} 60(\mathrm{OH}) 24$ in doxorubicin-induced hepatotoxicity in rats with mammary carcinomas, Biomaterials 29 (2008) 3451-3460.

[33] R. Injac, M. Perse, M. Cerne, N. Potocnik, N. Radic, B. Govedarica, A. Djordjevic, A. Cerar, B. Strukelj, Protective effects of fullerenol C60(OH)24 against doxorubicin-induced cardiotoxicity and hepatotoxicity in rats with colorectal cancer, Biomaterials 30 (2009) 1184-1196.

[34] A. Djordjević, M. Vojínović-Miloradov, N. Petranović, A. Devečerski, D. Lazar, B. Ribar, Catalytic Preparation and Characterization of C60Br24, Fullerene Sci. Technol. 6 (1998) 689-694.

[35] V.M. Torres, B. Srdjenovic, V. Jacevic, V.D. Simic, A. Djordjevic, A.L. Simplício, Fullerenol C60(OH)24 prevents doxorubicin-induced acute cardiotoxicity in rats, Pharmacol. Rep. 62 (2010) 707-718.

[36] J. Xu, Y. Su, J. Cheng, S. Li, R. Liu, W. Li, G. Xu, Q. Li, Protective effects of fullerenol on carbon tetrachloride-induced acute hepatotoxicity and nephrotoxicity in rats, Carbon 48 (2010) 1388-1396.

[37] P. Chaudhuri, A. Paraskar, S. Soni, R.A. Mashelkar, S. Sengupta, Fullerenol Cytotoxic Conjugates for Cancer Chemotherapy, ACS Nano 3 (2009) $2505-2514$.

[38] P. Chaudhuri, R. Harfouche, S. Soni, D.M. Hentschel, S. Sengupta, Shape Effect of Carbon Nanovectors on Angiogenesis, ACS Nano 4 (2010) 574-582. 
[39] V. Bogdanović, K. Stankov, I. Icević, D. Zikic, A. Nikolić, S. Solajić, A. Djordjević, G. Bogdanović, Fullerenol C60(OH)24 effects on antioxidative enzymes activity in irradiated human erythroleukemia cell line, J. Radiat. Res. 49 (2008) 321-327.

[40] K. Stankov, I. Borisev, V. Kojic, L. Rutonjski, G. Bogdanović, A. Djordjević, Modification of Antioxidative and Antiapoptotic Genes Expression in irradiated K562 Cells Upon Fullerenol C-60(OH)(24) Nanoparticle Treatment, J. Nanosci. Nanotechnol. 13 (2013) 105-113.

[41] H. Jin, W.Q. Chen, X.W. Tang, L.Y. Chiang, C.Y. Yang, J.V. Schloss, J.Y. Wu, Polyhydroxylated C(60), fullerenols, as glutamate receptor antagonists and neuroprotective agents, J. Neurosci. Res. 62 (2000) 600-607.

[42] Y. Saitoh, A. Miyanishi, H. Mizuno, S. Kato, H. Aoshima, K. Kokubo, N. Miwa, Super-highly hydroxylated fullerene derivative protects human keratinocytes from UV-induced cell injuries together with the decreases in intracellular ROS generation and DNA damages, J. Photochem. Photobiol. B 102 (2011) 69-76.

[43] H. An, B. Jin, Fullerenols and Fullerene Alter Cell Growth and Metabolisms of Escherichia coli, J. Biomed. Nanotechnol. 11 (2015) $1261-1268$.

[44] F. Fluri, D. Grünstein, E. Cam, U. Ungethuem, F. Hatz, J. Schäfer, S. Samnick, I. Israel, C. Kleinschnitz, G. Orts-Gil, H. Moch, T. Zeis, N. Schaeren-Wiemers, P. Seeberger, Fullerenols and glucosamine fullerenes reduce infarct volume and cerebral inflammation after ischemic stroke in normotensive and hypertensive rats, Exp. Neurol. 265 (2015) 142-151.

[45] F. Jiao, Y. Liu, Y. Qu, W. Li, G. Zhou, C. Ge, Y. Li, B. Sun, C. Chen, Studies on anti-tumor and antimetastatic activities of fullerenol in a mouse breast cancer model, Carbon 48 (2010) 2231-2243.

[46] J. Fan, G. Fang, F. Zeng, X. Wang, S. Wu, Water-Dispersible Fullerene Aggregates as a Targeted Anticancer Prodrug with both Chemo- and Photodynamic Therapeutic Actions, Small 9 (2013) 613-621.

[47] I. Lamparth, A. Hirsch, Water-soluble Malonic Acid Derivatives of C60 with a Defined Three-dimensional Structure, J. Chem. Soc. Chem. Commun. 1994 $1727-1728$.

[48] J. Yu, M. Guan, F. Li, Z. Zhang, C. Wang, C. Shu, H. Wei, X.E. Zhang, Effects of fullerene derivatives on bioluminescence and application for protease detection. Chem. Commun. (Camb.) 48 (2012) 11011-11013.

[49] I.C. Wang, L.A. Tai, D.D. Lee, P.P. Kanakamma, C.K. Shen, T.Y. Luh, C.H. Cheng, K.C. Hwang, C(60) and water-soluble fullerene derivatives as antioxidants against radical-initiated lipid peroxidation, J. Med. Chem. 42 (1999) 4614-4620.

[50] Y.L. Huang, C.K. Shen, T.Y. Luh, H.C. Yang, K.C. Hwang, C.K. Chou, Blockage of apoptotic signaling of transforming growth factor- $\beta$ in human hepatoma cells by carboxyfullerene, Eur. J. Biochem. 254 (1998) 38-43.

[51] S.S. Ali, J.I. Hardt, L.L. Dugan, SOD Activity of carboxyfullerenes predicts their neuroprotective efficacy: a structure-activity study, Nanomedicine: NBM, 4 (2008) 283-294.

[52] F. Chirico, C. Fumelli, A. Marconi, A. Tinari, E. Straface, W. Malorni, R. Pellicciari, C. Pincelli, Carboxyfullerenes localize within mitochondria and prevent the UVB-induced intrinsic apoptotic pathway, Exp. Dermatol. 16 (2007) 429-436.

[53] K.L. Quick, S.S. Ali, R. Arch, C. Xiong, D. Wozniak, L.L. Dugan, A carboxyfullerene SOD mimetic improves cognition and extends the lifespan of mice. Neurobiol, Aging 29 (2008) 117-128.

[54] T. Komatsu, A. Nakagawa, X. Qu, Structural and Mutagenic Approach to Create Human Serum Albumin-Based Oxygen Carrier and Photosensitizer, Drug Metab. Pharmacokinet. 24 (2009) 287-299.

[55] C. Kojima, K. Kono, K. Maruyama, T. Takagishi, Synthesis of polyamidoamine dendrimers having poly(ethylene glycol) grafts and their ability to encapsulate anticancer drugs, Bioconjug. Chem. 11 (2000) 910-917.

[56] X. Li, Y. Watanabe, E. Yuba, A. Harada, T. Haino, K. Kono, Facile construction of well-defined fullerene-dendrimer supramolecular nanocomposites for bioapplications, Chem. Commun. 51 (2015) 2851-2854.

[57] M. Maggini, G. Scorrano, M. Prato, Addition of Azomethine Ylides to CM: Synthesis, Characterization, and Functionalization of Fullerene Pyrrolidines, J. Am. Chem. Soc. 115 (1993) 9798-9799. 
[58] T. Mashino, N. Usui, K. Okuda, T. Hirota, M. Mochizuki, Respiratory Chain Inhibition by Fullerene Derivatives: Hydrogen Peroxide Production Caused by Fullerene Derivatives and a Respiratory Chain System, Bioorg. Med. Chem. 11 (2003) 1433-1438.

[59] T. Mashino, K. Okuda, T. Hirota, M. Hirobe, T. Nagano, M. Mochizuki, Inhibition of E. coli growth by fullerene derivatives and inhibition mechanism, Bioorg. Med. Chem. Lett. 9 (1999) 2959-2962.

[60] T. Mashino, D. Nishikawa, K. Takahashi, N. Usui, T. Yamori, M. Seki, T. Endo, M. Mochizuki, Antibacterial and Antiproliferative Activity of Cationic Fullerene Derivatives, Bioorg. Med. Chem. Lett. 13 (2003) 4395-4397.

[61] M.E. Milanesio, M.B. Spesia, M.P. Cormick, E.N. Durantini, Mechanistic studies on the photodynamic effect induced by a dicationic fullerene C $_{60}$ derivative on Escherichia coli and Candida albicans cells, Photodiagnosis Photodyn. Ther. 10 (2013) 320-327.

[62] GP. Tegos, T.N. Demidova, D. Arcila-Lopez, H. Lee, T. Wharton, H. Gali, M.R. Hamblin, Cationic fullerenes are effective and selective antimicrobial photosensitizers, Chem. Biol. 12 (2005) 1127-1135.

[63] L.Y. Huang, M. Terakawa, T. Zhiyentayev, Y.Y. Huang, Y. Sawayama, A. Jahnke, G.P. Tegos, T. Wharton, M.R. Hamblin, Novel cationic fullerenes as broadspectrum light-activated antimicrobials, Nanomedicine 6 (2010) 442-452.

[64] M.B. Spesia, M.E. Milanesio, E.N. Durantini, Synthesis, properties and photodynamic inactivation of Escherichia coli by novel cationic fullerene C $_{60}$ derivatives, Eur. J. Med. Chem. 43 (2008) 853-861.

[65] S.A. Lambrechts, M.C. Aalders, D.H. Langeveld-Klerks, Y. Khayali, J.W. Lagerberg, Effect of monovalent and divalent cations on the photoinactivation of bacteria with meso-substituted cationic porphyrins, Photochem Photobiol. 79 (2004) 297-302.

[66] M.B. Patel, U. Harikrishnan, N.N. Valand, N.R. Modi, S.K. Menon, Novel Cationic Quinazolin-4(3H)-one Conjugated Fullerene Nanoparticles as Antimycobacterial and Antimicrobial Agents, Arch. Pharm. Chem. Life Sci. 346 (2013) 210-220.

[67] A. Kumar, G. Patel, S.K. Menon, Fullerene Isoniazid Conjugate - A Tuberculostat with Increased Lipophilicity: Synthesis and Evaluation of Antimycobacterial Activity, Chem. Biol. Drug Des. 73 (2009) 553-557.

[68] M.B. Patel, S.P. Kumar, N.N. Valand, Jasrai, Y.T.; S.K. Menon, Synthesis and biological evaluation of cationic fullerene quinazolinone conjugates and their binding mode with modeled Mycobacterium tuberculosis hypoxanthine-guanine phosphoribosyltransferase enzyme, J. Mol. Model 19 (2013) $3201-3217$.

[69] S. Takenaka, K. Yamashita, M. Takagi, T. Hatta, O. Tsuge, DNA coated with cationic fullerene derivative. A possible microwire in water. Nucleic Acids Symp. Ser. (Oxf) 42 (1999) 149-150.

[70] M.B. Patel, U. Harikrishnan, N.N. Valand, D.S. Mehta, K.V. Joshi, S.P. Kumar, K.H. Chikhalia, L.B. George, Y.T. Jasrai, S.K. Menon, Novel cationic fullerene derivatized s-triazine scaffolds as photoinduced DNA cleavage agents: design, synthesis, biological evaluation and computational investigation, RSC Advances 3 (2013) 8734-8746.

[71] Z. Hu, W. Guan, W. Wang, L. Huang, X. Tang, H. Xu, Z. Zhu, X. Xie, H. Xing, Synthesis of amphiphilic amino acid C60 derivatives and their protective effect on hydrogen peroxide-induced apoptosis in rat pheochromocytoma cells, Carbon 46 (2008) 99-109.

[72] T. Chen, Y.Y. Li, J.L. Zhang, B. Xu, Y. Lin, C.X. Wang, W.C. Guan, Y.J. Wang, S.Q. Xu, Protective effect of C(60) -methionine derivate on lead-exposed human SH-SY5Y neuroblastoma cells, J. Appl. Toxicol. 31 (2011) 255-261.

[73] Z. Li, F. Zhang, Z. Wang, L. Pan, Y. Shen, Z. Zhang, Fullerene (C60) nanoparticles exert photocytotoxicity through modulation of reactive oxygen species and p38 mitogen-activated protein kinase activation in the MCF-7 cancer cell line, J. Nanopart. Res. 15 (2013) 2102-2112.

[74] D. Iohara, M. Hiratsuka, F. Hirayama, K. Takeshita, K. Motoyama, H. Arima, K. Uekama, Evaluation of photodynamic activity of $\mathrm{C}_{60} / 2$-hydroxypropyl- $\beta$ cyclodextrin nanoparticles, J. Pharm. Sci. 101 (2012) 3390-3397.

[75] A. Abdulmalik, A. Hibah, B.M. Zainy, A. Makoto, I. Daisuke, O. Masaki, U. Kaneto, H. Fumitoshi, Preparation of soluble stable C60/human serum albumin nanoparticles via cyclodextrin complexation and their reactive oxygen production characteristics, Life Sci. 93 (2013) 277-282.

[76] R.A. Kotelnikova, A. Kotelnikov, G.N. Bogdanov, V.S. Romanova, E.F. Kuleshova, Z.N. Parnes, M.E. Vol'pin, Membranotropic properties of the water soluble amino acid and peptide derivatives of fullerene C60, FEBS Lett. 389 (1996) 111-114. 
[77] R. Barron, J.Z. Yang, A new route to fullerene substituted phenylalanine derivatives, Chem. Commun. 24 (2004) $2884-2885$.

[78] J.Z. Yang, K. Wang, J. Driver, J.H. Yang, A.R. Barron, The use of fullerene substituted phenylanine amino acid as a passport for peptides through cell membranes, Org. Biomol. Chem. 5 (2007) 260-266.

[79] J.G. Rouse, J. Yang, J.P. Ryman-Rasmussen, A.R. Barron, N.A. Monteiro-Riviere, Effects of mechanical flexion on the penetration of fullerene amino acidderivatized peptide nanoparticles through skin, Nano Lett. 7 (2007) 155-160.

[80] Y. Xu, J. Zhu, K. Xiang, Y. Li, R. Sun, J. Ma, H. Sun, Y. Liu, Synthesis and immunomodulatory activity of [60]fullerene-tuftsin conjugates, Biomaterials 32 (2011) 9940-9949.

[81] S.H. Friedman, D.L. Decamp, R.P. Sijbesma, G. Srdanov, F. Wudl, G.L. Kenyon, Inhibition of the HIV-1 Protease by Fullerene Derivatives: Model Building Studies and Experimental Verification, J. Am. Chem. Soc. 115 (1993) 6506-6509.

[82] C. Toniolo, A. Bianco, M. Maggini, G. Scorrano, M. Prate, M. Marastoni, R. Tomatis, S. Spisani, G. Palu, E.D. Blair, A Bioactive Fullerene Peptide, J. Med. Chem. 37 (1994) 4558-4562.

[83] T. Mashino, K. Shimotohno, N. Ikegami, D. Nishikawa, K. Okuda, K. Takahashi, S. Nakamura, M. Mochizuki, Human immunodeficiency virus-reverse transcriptase inhibition and hepatitis C virus RNA-dependent RNA polymerase inhibition activities of fullerene derivatives, Bioorg. Med. Chem. Lett. 15 (2005) 1107-1109.

[84] S. Durdagi, C.T. Supuran, T.A. Strom, N. Doostdar, M.K. Kumar, A.R. Barron, T. Mavromoustakos, M.G. Papadopoulos, In Silico Drug Screening Approach for the Design of Magic Bullets: A Successful Example with Anti-HIV Fullerene Derivatized Amino Acids, J. Chem. Inf. Model. 49 (2009) $1139-1143$.

[85] M. Horie, A. Fukuhara, Y. Saito, Y. Yoshida, H. Sato, H. Ohi, M. Obata, Y. Mikata, S. Yano, E. Niki, Antioxidant action of sugar-pendant C60 fullerenes, Bioorg. Med. Chem. Lett. 19 (2009) 5902-5904.

[86] Y. Mikata, S. Takagi, M. Tanahashi, S. Ishii, M. Obata, Y. Miyamoto, K. Wakita, T. Nishisaka, T. Hirano, T. Ito, M. Hoshino, C. Ohtsuki, M. Tanihara, S. Yano, Detection of $1270 \mathrm{~nm}$ Emission from Singlet Oxygen and Photocytotoxic Property of Sugar-Pendant [60]Fullerenes, Bioorg. Med. Chem. Lett. 13 (2003) $3289-3292$.

[87] S. Tanimoto, S. Sakai, S. Matsumura, D. Takahashi, K. Toshima, Target-selective photo-degradation of HIV-1 protease by a fullerene-sugar hybrid, Chem. Commun. (Camb). 44 (2008) 5767-5769.

[88] S. Tanimoto, S. Sakai, E. Kudo, S. Okada, S. Matsumura, D. Takahashi, K. Toshima, Target-Selective Photodegradation of HIV-1 Protease and Inhibition of HIV-1 Replication in Living Cells by Designed Fullerene-Sugar Hybrids, Chem. Asian J. 7 (2012) 911-914.

[89] R. Rísquez-Cuadro, J.M. García Fernández, J.F. Nierengarten, C. Ortiz Mellet, Fullerene-sp2-Iminosugar Balls as Multimodal Ligands for Lectins and Glycosidases: A Mechanistic Hypothesis for the Inhibitory Multivalent Effect, Chemistry 19 (2013) 16791-16803.

[90] I. Nierengarten, J.F. Nierengarten, Fullerene Sugar Balls: A New Class of Biologically Active Fullerene Derivatives, Chem. Asian J. 9 (2014) $1436-1444$.

[91] J. Luczkowiak, A. Muñoz, M. Sánchez-Navarro, R. Ribeiro-Viana, A. Ginieis, B.M. Illescas, N. Martín, R. Delgado, J. Rojo, Glycofullerenes Inhibit Viral Infection, Biomacromolecules 14 (2013) 431-437.

[92] M. Sánchez-Navarro, A. Muñoz, B.M. Illescas, J. Rojo, N. Martín, [60]Fullerene as Multivalent Scaffold: Efficient Molecular Recognition of Globular Glycofullerenes by Concanavalin A, Chemistry 17 (2011) 766-769.

[93] R. Bernstein, F. Prat, C. S. Foote, On the Mechanism of DNA Cleavage by Fullerenes Investigated in Model Systems: Electron Transfer from Guanosine and 8Oxo-Guanosine Derivatives to $\mathrm{C}_{60}$, J. Am. Chem. Soc. 121 (1999) 464-465.

[94] S. Samal, K.E. Geckeler, Cyclodextrin-fullerenes: a new class of water-soluble fullerenes, Chem. Commun. 13 (2000) $1101-1102$.

[95] Y. Liu, L.Y. Zhao, Y. Chen, P. Liang, L. Li, A water-soluble $\beta$-cyclodextrin derivative possessing a fullerene tether as an efficient photodriven DNA-cleavage reagent, Tetrahedron Lett. 46 (2005) 2507-2511.

[96] J.J. Wang, Z.H. Zhang, W. Wu, X.Q. Jiang, Synthesis of $\beta$-Cyclodextrin-[60]fullerene Conjugate and Its DNA Cleavage Performance, Chin. J. Chem. 32 (2014) $78-84$. 
[97] T. Andersson, G. Westman, O. Wennerström, M. Sundahl, NMR and UV-VIS Investigation of Water-soluble Fullerene-60- $\gamma$-Cyclodextrin Complex, J. Chem. Soc. Perkin Trans. 25 (1994) 1097-1101.

[98] B.Z. Zhao, Y.Y. He, P.J. Bilski, C.F. Chignell, Pristine (C60) and Hydroxylated [C60(OH)24] Fullerene Phototoxicity towards HaCaT Keratinocytes: Type I vs Type II Mechanisms, Chem. Res. Toxicol. 21 (2008) 1056-1063.

[99] B.Z. Zhao, Y.Y. He, C.F. Chignell, J.J. Yin, U. Andley, J.E. Roberts, Difference in Phototoxicity of Cyclodextrin Complexed Fullerene [( $\gamma$-CyD)2/C60] and Its Aggregated Derivatives toward Human Lens Epithelial Cells, Chem. Res. Toxicol. 22 (2009) 660-667.

[100] K. Nobusawa, M. Akiyama, A. Ikeda, M. Naito, pH responsive smart carrier of [60] fullerene with 6-amino-cyclodextrin inclusion complex for photodynamic therapy, J. Mater. Chem. 22 (2012) 22610-22613.

[101] A. Ikeda, T. Iizuka, N. Maekubo, R. Aono, J. Kikuchi, M. Akiyama, T. Konishi, T. Ogawa, N. Ishida-Kitagawa, H. Tatebe, K. Shiozaki, Cyclodextrin complexed [60]fullerene derivatives with high levels of photodynamic activity by long wavelength excitation, ACS Med. Chem. Lett. 4 (2013) $752-756$.

[102] A. Ikeda, T. Sue, M. Akiyama, K. Fujioka, T. Shigematsu, Y.K. Doi, J. Kikuchi, T. Konishi, R. Nakajima, Preparation of Highly Photosensitizing Liposomes with Fullerene-Doped Lipid Bilayer Using Dispersion-Controllable Molecular Exchange Reactions, Org. Lett. 10 (2007) 4077-4080.

[103] A. Ikeda, M. Mori, K. Kiguchi, K. Yasuhara, J. Kikuchi, K. Nobusawa, M. Akiyama, M. Hashizume, T. Ogawa, T. Takeya, Advantages and potential of lipidmembrane-incorporating fullerenes prepared by the fullerene-exchange method, Chem. Asian J. 7 (2012) 605-613.

[104] A. Ikeda, Sato, T.; Kitamura, K.; Nishiguchi, K.; Sasaki, Y.; Kikuchi, J.; Ogawa, T.; Yogo, K.; Takeya, T. Efficient photocleavage of DNA utilising watersoluble lipid membrane-incorporated [60]fullerenes prepared using a [60]fullerene exchange method. Org. Biomol. Chem. 3 (2005) 2907-2909.

[105] Y.K. Doi, A. Ikeda, M. Akiyama, M. Nagano, T. Shigematsu, T. Ogawa, T. Takeya, T. Nagasaki, Intracellular Uptake and Photodynamic Activity of WaterSoluble[60]- and [70]Fullerenes Incorporated in Liposomes, Chem. Eur. J. 14 (2008) 8892-8897.

[106] M. Akiyama, A. Ikeda, T. Shintani, Y. Doi, J. Kikuchi, T. Ogawa, K. Yogo, T. Takeya, N. Yamamoto, Solubilisation of [60]fullerenes using block copolymers and evaluation of their photodynamic activities, Org. Biomol. Chem. 6 (2008) 1015-1019.

[107] S. Kato, R. Kikuchi, H. Aoshima, Y. Saitoh, N. Miwa, Defensive effects of fullerene-C60/liposome complex against UVA-induced intracellular reactive oxygen species generation and cell death in human skin keratinocytes $\mathrm{HaCaT}$, associated with intracellular uptake and extracellular excretion of fullerene- $\mathrm{C}_{60}$, J. Photochem. Photobiol. B. 98 (2010) 144-151.

[108] S. Kato, H. Aoshima, Y. Saitoh, N. Miwa, Fullerene-C 60 liposome complex: Defensive effects against UVA-induced damages in skin structure, nucleus and collagen type I/IV fibrils, and the permeability into human skin tissue, J. Photochem. Photobiol. B. 98 (2010) 99-105.

[109] C. Du, H. Xiong, H. Ji, Q. Liu, H. Xiao, Z. Yang, The antiviral effect of fullerene-liposome complex against influenza virus (H1N1) in vivo, Sci. Res. Essays, 7 (2012) 705-711.

[110] L. Xiao, H. Takada, K. Maeda, M. Haramoto, N. Miwa, Antioxidant effects of water-soluble fullerene derivatives against ultraviolet ray or peroxylipid through their action of scavenging the reactive oxygen species in human skin keratinocytes, Biomed. Pharmacother. 59 (2005) 351-358.

[111] L. Xiao, K. Matsubayashi, N. Miwa, Inhibitory eVect of the water-soluble polymer-wrapped derivative of fullerene on UVA-induced melanogenesis via downregulation of tyrosinase expression in human melanocytes and skin tissues, Arch. Dermatol. Res. 299 (2007) 245-257.

[112] S. Kato, H. Aoshima, Y. Saitoh, N. Miwa, Biological Safety of LipoFullerene composed of Squalane and Fullerene-C60 upon Mutagenesis, Photocytotoxicity, and Permeability into the Human Skin Tissue, Basic Clin. Pharmacol. Toxicol. 104 (2009) 483-487.

[113] G.E. Magoulas, M. Bantzi, D. Messari, E. Voulgari, C. Gialeli, D. Barbouri, A. Giannis, N.K. Karamanos, D. Papaioannou, K. Avgoustakis, Synthesis and Evaluation of Anticancer Activity in Cells of Novel Stoichiometric Pegylated Fullerene-Doxorubicin Conjugates, Pharm. Res. 32 (2015) 1676-1693.

[114] G. Zhou, I.I. Harruna, W.L. Zhou, W.K. Aicher, K.E. Geckeler, Nanostructured Thermosensitive Polymers with Radical Scavenging Ability, Chem. Eur. J. 13 (2007) 569-573. 
[115] Y. Iwamoto, Y. Yamakoshi, A highly water-soluble $\mathrm{C}_{60}-\mathrm{NVP}$ copolymer: a potential material for photodynamic therapy, Chem. Commun. 46 (2006) 48054807.

[116] S. Oriana, S. Aroua, J.O. Söllner, X.J. Ma, Y. Iwamoto, Y. Yamakoshi, Water-soluble C60- and C70-PVP polymers forbiomaterials with efficient 1O2 generation, Chem. Commun. 49 (2013) 9302-9304.

[117] M. Hurtgen, A. Debuigne, A. Mouithys-Mickalad, R. Jérôme, C. Jérôme, C. Detrembleur, Synthesis of Poly(vinyl alcohol)/C60 and Poly(Nvinylpyrrolidone)/C60 Nanohybrids as Potential Photodynamic Cancer Therapy Agents, Chem. Asian J. 5 (2010) 859-868.

[118] M. Hurtgen, A. Debuigne, C.A. Fustin, C. Jérôme, C. Detrembleur, Organometallic-Mediated Radical Polymerization: Unusual Route toward (Quasi-) Diblock Graft Copolymers Starting from a Mixture of Monomers of Opposed Reactivity, Macromolecules, 44 (2011) 4623-4631.

[119] Y. Matsumura, H. Maeda, A New Concept for Macromolecular Therapeutics in Cancer Chemotherapy: Mechanism of Tumoritropic Accumulation of Proteins and the Antitumor Agent Smancs, Cancer Res. 46 (1986) 6387-6392.

[120] M. Hurtgen, A. Debuigne, M. Hoebeke, C. Passirani, N. Lautram, A. Mouithys-Mickalad, P.H. Guelluy, C. Jérôme, C. Detrembleur, Photochemical Properties and Activity of Water-Soluble Polymer/C 60 Nanohybrids for Photodynamic Therapy, Macromol. Biosci. 13 (2013) 106-115.

[121] S. Yusa, S. Awa, M. Ito, T. Kawase, T. Takada, K. Nakashima, D. Liu, S. Yamago, Y. Morishima, Solubilization of C60 by Micellization with a Thermoresponsive Block Copolymer in Water: Characterization, Singlet Oxygen Generation, and DNA Photocleavage, J. Polym. Sci. Pol. Chem. 49 (2011) 27612770 .

[122] Y. Ishida, S. Tanimoto, D. Takahashi, K. Toshima, Photo-degradation of amyloid b by a designed fullerene-sugar hybrid, Med. Chem. Commun. 1 (2010) 212215.

[123] J. Shi, X. Yu, L. Wang, Y. Liu, J. Gao, J. Zhang, R. Ma, R. Liu, Z. Zhang, PEGylated fullerene/iron oxide nanocomposites for photodynamic therapy, targeted drug delivery and MR imaging, Biomaterials 34 (2013) 9666-9677.

[124] J. Liu, S. Ohta, A. Sonoda, M. Yamada, M. Yamamoto, N. Nitta, K. Murata, Y. Tabata, Preparation of PEG-conjugated fullerene containing Gd3+ ions for photodynamic therapy, J. Control Release 117 (2007) 104-110.

[125] B. Du, S. Han, H. Li, F. Zhao, X. Su, X. Cao, Z. Zhang, Multi-functional liposomes showing radiofrequency-triggered release and magnetic resonance imaging for tumor multi-mechanism therapy, Nanoscale 7 (2015) 5411-5426.

[126] Z. Hu, J. Li, Y. Huang, L. Chen, Z. Li, Functionalized graphene/C 60 nanohybrid for targeting photothermally enhanced photodynamic therapy, RSC Adv. 5 (2015) 654-664.

[127] D.J. Lee, Y.S. Ahn, Y.S. Younb, E.S. Lee, Poly(ethylene glycol)-crosslinked fullerenes for high efficient phototherapy, Polym. Adv. Technol. 24 (2013) 220227.

[128] X. Liu, M. Zheng, X. Kong, Y. Zhang, Q. Zeng, Z. Sun, W.J. Buma, H. Zhang, Separately doped upconversion-C 60 nanoplatform for NIR imaging-guided photodynamic therapy of cancer cells, Chem. Commun. (Camb) 49 (2013) 3224-3226.

[129] U.M. Uritu, C.D. Varganici, L. Ursu, A. Coroaba, A. Nicolescu, A.I. Dascalu, D. Peptanariu, D. Stan, C.A. Constantinescu, V. Simion, M. Calin, S.S. Maier, M. Pinteala, M. Barboiu, Hybrid fullerene conjugates as vectors for DNA cell-delivery, J. Mater. Chem. B 3 (2015) 2433-2446.

[130] Z. Dou, Y. Xu, H. Sun, Y. Liu, Synthesis of PEGylated fullerene-5-fluorouracil conjugates to enhance the antitumor effect of 5-fluorouracil, Nanoscale 4 (2012) $4624-4630$.

[131] J.L. Gilmore, X. Yi, L. Quan, A.V. Kabanov, Novel nanomaterials for clinical neuroscience, J. Neuroimmune Pharmacol. 3 (2008) $83-94$.

[132] C.M. Lee, S.T. Huang, S.H. Huang, H.W. Lin, H.P. Tsai, J.Y. Wu, C.M. Lin, C.T. Chen, Co $_{60}$ fullerene-pentoxifylline dyad nanoparticles enhance autophagy to avoid cytotoxic effects caused by the $\beta$-amyloid peptide, Nanomedicine 7 (2011) 107-114.

[133] A. Ikeda, Y. Doi, K. Nishiguchi, K. Kitamura, M. Hashizume, J. Kikuchi, K. Yogo, T. Ogawa, T. Takeya, Induction of cell death by photodynamic therapy with water-soluble lipid-membrane-incorporated [60]fullerene, Org. Biomol. Chem. 5 (2007) 1158-1160. 
[134] W. Cong, P. Wang, Y. Qu, J. Tang, R. Bai, Y. Zhao, C.Y. Chen, X. Bi. Evaluation of the influence of fullerenol on aging and stress resistance using Caenorhabditis elegans. Biomaterials. 42 (2015) 78-86.

[135] F. Fluri, D. Grünstein, E. Cam, U. Ungethuem, F. Hatz, J. Schäfer, S. Samnick, I. Israel, C. Kleinschnitz, G. Orts-Gil, H. Moch, T. Zeis, N. Schaeren-Wiemers, P. Seeberger. Fullerenols and glucosamine fullerenes reduce infarct volume and cerebral inflammation after ischemic stroke in normotensive and hypertensive rats. Exp. Neurol. 265 (2015) 142-151.

[136] H. An, B. Jin. Fullerenols and Fullerene Alter Cell Growth and Metabolisms of Escherichia coli. J. Biomed. Nanotechnol. 11 (2015) 1261-1268

[137] M. Prato. [60]Fullerene chemistry for materials science applications. J. Mater. Chem. 7 (1997), 1097-1109.

[138] E.B. Zeynalov, N.S. Allen, N.I. Salmanova. Radical scavenging efficiency of different fullerenes $\mathrm{C}_{60}-\mathrm{C}_{70}$ and fullerene soot. Polymer Degrad. Stabil. 94 (2009) $1183-1189$.

[139] M. Carini, L. Đordevic, T. D. Ros. Fullerenes in Biology and Medicine. Handbook of Carbon Nano Materials. Volume 3: Medicinal and Bio-related Applications. 2012 by World Scientific Publishing Co. Pte. Ltd.

[140] A.W. Jensen, S.R. Wilson, D.I. Schuster. Biological applications of fullerenes. Bioorg. Med. Chem. 4 (1996) 767-779.

[141] S.Z. Wang, R.M. Gao, F.M. Zhou, M. Selke. Nanomaterials and singlet oxygen photosensitizers: potential applications in photodynamic therapy. J. Mater. Chem. 14 (2004) 487-493.

[142] A. Trpkovic, B. Todorovic-Markovic, V. Trajkovic. Toxicity of pristine versus functionalized fullerenes: mechanisms of cell damage and the role of oxidative stress. Arch. Toxicol. 86 (2012), 1809-1827.

[143] M. Prato, D.M. Guldi. Excited-state properties of $C_{60}$ fullerene derivatives. Acc. Chem. Res. 33 (2000) 695-703.

[144] L.L. Dugan, D.M. Turetsky, C. Du, D. Lobner, M. Wheeler, C.R. Almli, C.K. Shen, T.Y. Luh, D.W. Choi, T.S. Lin. Carboxyfullerenes as neuroprotective agents. Proc. Natl. Acad. Sci. U S A. 94 (1997) 9434-9439.

[145] F. Prat, R. Stackow, R. Bernstein, W.Y. Qian, Y. Rubin, C.S. Foote. Triplet-State Properties and Singlet Oxygen Generation in a Homologous Series of Functionalized Fullerene Derivatives. J. Phys. Chem. A, 103 (1999) 7230-7235.

[146] F.Y. Cheng, X.L. Yang, H.S. Zhu. Hydroxyl radical scavenging and producing activities of water-soluble malonic acid C60. Fullerene Sci. Techn., 8(2000) 113124.

[147] N. Gharbi, M. Pressac, M. Hadchouel, H. Szwarc, S.R. Wilson, F. Moussa. [60]Fullerene is a Powerful Antioxidant in Vivo with No Acute or Subacute Toxicity. Nano Lett. 5 (2005) 2578-2585. 
Highlight:

- Hydrophilic $\mathrm{C}_{60}$ derivatives $\left(\mathrm{hC}_{60} \mathrm{~s}\right)$ serve as reactive oxygen species (ROS) producer, radical scavenger, $\mathrm{O}_{2}$ uptake inhibitor, HIV inhibitor and vectors for DNA or drugs.

- Although each hydrophilic $\mathrm{C}_{60}$ derivative has the potential to be both, they show a preference. The propensity is dependent on $\mathrm{C}_{60}$ s structure.

- High ${ }^{1} \mathrm{O}_{2}$ quantum yield means low aggregation. $\mathrm{C}_{60}$ s with aggregates scarcely generate ${ }^{1} \mathrm{O}_{2}$, but $\mathrm{O}_{2}{ }^{--}$.

- The typical reactions to get covalent $\mathrm{C}_{60} \mathrm{~s}$ are oxidation, Bingel reaction, Prato reaction, Diel-Alder reaction and radical polymerization. 